\title{
Closure Report for the Central Facilities Area Sewage Treatment Plant Lagoon 3 and Land Application Area
}

November 2017

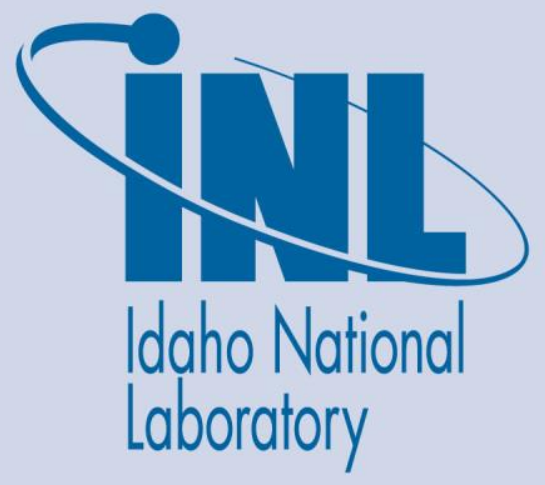

The INL is a U.S. Department of Energy National Laboratory operated by Battelle Energy Alliance 

INL/EXT-17-43761

Revision 0

\section{Closure Report for the Central Facilities Area Sewage Treatment Plant Lagoon 3 and Land Application Area}

November 2017

Idaho National Laboratory Idaho Falls, Idaho 83415

http://www.inl.gov

Prepared for the U.S. Department of Energy

Office of Nuclear Energy, Science, and Technology

Under DOE Idaho Operations Office

Contract DE-AC07-05ID14517 



\section{ABSTRACT}

Because of significantly reduced wastewater discharges to the Central Facilities Area Sewage Treatment Plant, wastewater has not been land applied since 2011. The future need to land apply wastewater was evaluated. Based on the current wastewater flows into the Central Facilities Area Sewage Treatment Plant, expected future missions at Central Facilities Area, and the discovery in 2014 that Lagoon 3 was leaking at an unacceptable rate, it was determined that the Central Facilities Area Sewage Treatment Plant is significantly oversized and that Lagoons 1 and 2 could be converted to total evaporation lagoons. Therefore, the decision was made to remove the existing sludge in Lagoon 3 and transfer it to Lagoon 2 for additional treatment, decommission Lagoon 3 and the land application area, and terminate the wastewater reuse permit.

A closure plan was submitted and approved by the Idaho Department of Environmental Quality in 2016. This report describes the closure activities that were performed. Closure activities included:

- Characterizing the soil/liner in Lagoon 3 to determine whether further characterization and/or remediation will be required under the Comprehensive Environmental Response, Compensation, and Liability Act.

- Based on the results from the soil/liner sampling, determining whether additional sampling will be required for the land application area.

- Removing the sludge in Lagoon 3 and placing it in Lagoon 2.

- Puncturing the Lagoon 3 soil/liner to prevent ponding of storm water and becoming a source for vectors.

- Installing a permanent cap on the inlet piping to Lagoon 3.

Samples were collected on November 10, 2016, and were submitted for analysis to an off-site laboratory. Data validation and evaluation were performed by Portage, INC. Sample results confirmed that there is no hazard to human health and the environment and that Lagoon 3 and the land application area could be closed.

In August 2017, sludge was removed from Lagoon 3 and placed in Lagoon 2, the soil/liner was punctured in 4 places, and caps were installed on the primary and bypass inlet lines. 


\section{CONTENTS}

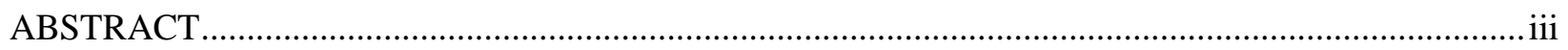

ACRONYMS

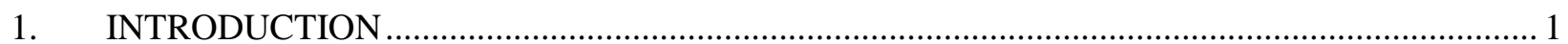

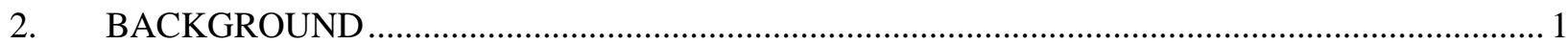

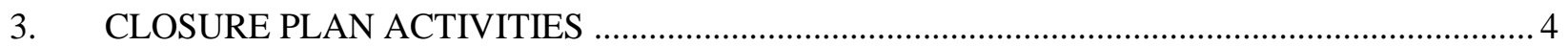

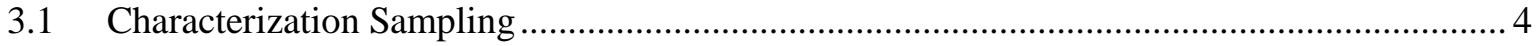

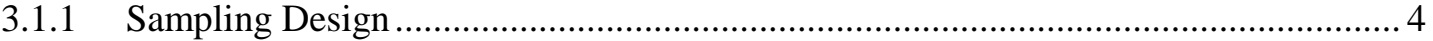

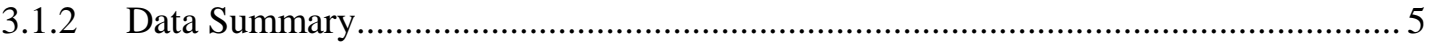

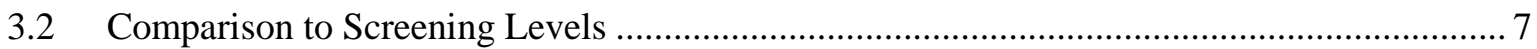

3.3 Summary Information for Copper, Lead, Manganese, Selenium, and Thallium ................... 8

3.4 Evaluation of Parameters Exceeding Ecological Screening Levels ..................................... 12

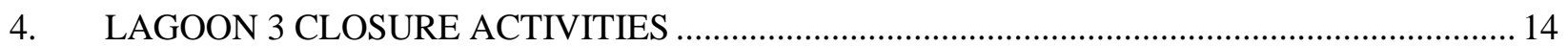

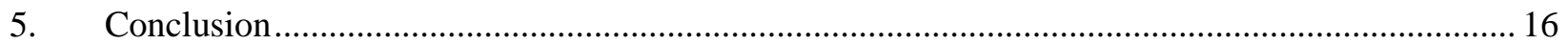

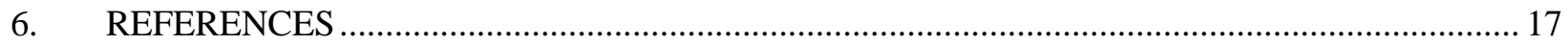

Appendix A Soil/Liner Sample Data from Central Facilities Area Sewage Treatment Plant Lagoon 3 ... 19

\section{FIGURES}

Figure 1. Map showing location of the Central Facilities Area Sewage Treatment Plant. ........................ 3

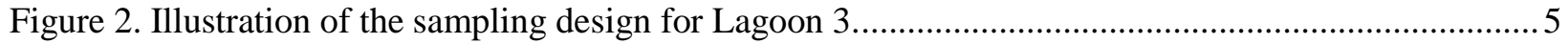

Figure 3. Dried sludge in the bottom of the Central Facilities Area Sewage Treatment Plant Lagoon 3... 14

Figure 4. Cap placed on primary inlet pipe. .15

Figure 5. Photo showing Central Facilities Area Sewage Treatment Plant Lagoon 3 after all work was completed. 


\section{TABLES}

Table 1. Detected and undetected analytes from the Lagoon 3 soil/liner sampling event. ........................ 7

Table 2. Summary statistics for analytes detected in the Lagoon 3 soil/liner samples. ............................ 7

Table 3. Comparison of data to background and screening levels associated with the closure of

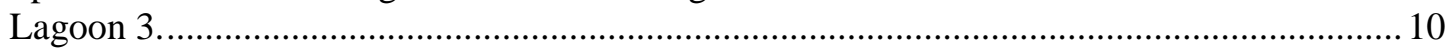

Table 4. Results of ecological risk evaluation for specific metals. ......................................................... 13

Table 5. Comparison of sample maximum concentrations to the Idaho National Laboratory Site soil background levels, Comprehensive Environmental Response, Compensation, and Liability Act ecological screening levels, and the Environmental Protection Agency sewage sludge pollutant concentrations. .......................................................................... 13

Table A-1. Central Facilities Area Sewage Treatment Plant Lagoon 3 soil/liner metals sample data........21

Table A-2. Central Facilities Area Sewage Treatment Plant Lagoon 3 soil/liner organic sample data......27

Table A-3. Central Facilities Area Sewage Treatment Plant Lagoon 3 soil/liner radiological sample data. 


\section{ACRONYMS}

BEA Battelle Energy Alliance, LLC

$\mathrm{CCN} \quad$ correspondence control number

CERCLA Comprehensive Environmental Response, Compensation, and Liability Act

CFA Central Facilities Area

DEQ Idaho Department of Environmental Quality

DOE-ID U. S. Department of Energy Idaho Operations Office

ESL ecological screening level

EPA U.S. Environmental Protection Agency

FSP field sampling plan

GEL GEL Laboratories, LLC

HQ Hazard Quotient

INL Idaho National Laboratory

LAA land application area

$\mathrm{mg} / \mathrm{kg} \quad$ milligrams/kilogram

QAPP Quality Assurance Project Plan

RCRA Resource Conservation and Recovery Act

SAP sampling and analysis plan

STP Sewage Treatment Plant

TCLP Toxicity Characteristic Leaching Procedure

ug/kg microgram/kilogram

WRP Wastewater Reuse Permit 


\section{Closure Report for the Central Facilities Area Sewage Treatment Plant Lagoon 3 and Land Application Area 1. INTRODUCTION}

The Central Facilities Area (CFA) Sewage Treatment Plant (STP) is a municipal wastewater facility operated by Battelle Energy Alliance, LLC (BEA), under Wastewater Reuse Permit (WRP) LA-000141-03 issued by the State of Idaho, Department of Environmental Quality (DEQ). The WRP was issued on March 17, 2010 (Neher 2010). The WRP expired on March 16, 2015; however, the CFA STP continues to operate under the terms and conditions of WRP LA-000141-03.

Because of significantly reduced wastewater discharges to the CFA STP, wastewater has not been land applied since 2011. The future need to land apply wastewater was evaluated. Based on the current wastewater flows into the CFA STP and expected future missions at CFA, it was determined that the CFA STP is significantly oversized and that Lagoons 1 and 2 could be converted to total evaporation lagoons. Therefore, the decision was made to remove the existing sludge in Lagoon 3 and transfer it to Lagoon 2 for additional treatment, decommission Lagoon 3, close the land application area (LAA), and terminate the WRP.

On December 17, 2014, personnel from DEQ, BEA, and the U.S. Department of Energy Idaho Operations Office (DOE-ID) met to discuss closure of Lagoon 3 and the LAA (73.5 acres) and the termination of the WRP (Lewis 2014). It was determined that Lagoon 3 could be left in place and did not have to be filled with soil. On February 23, 2015, the closure plan was submitted (Miller 2015) to DEQ. Comments on the closure plan were received from DEQ (Rackow 2015) on June 16, 2015. Following evaluation of the comments from DEQ and further investigation by DEQ and BEA of the sludge disposal requirements, a meeting was held on February 4, 2016 (Lewis 2016). At this meeting, it was agreed to by all parties that the best approach for handling the sewage sludge in Lagoon 3 would be to scrape up the sludge and discharge it into CFA STP Lagoon 2.

The closure plan was revised and resubmitted (Miller 2016a) to DEQ for review and approval on May 6, 2016. On July 5, 2016, DEQ approved (Rackow 2016a) the closure plan.

This report documents the closure of CFA STP Lagoon 3 and the LAA in accordance with the approved closure plan. Because the CFA STP is now an evaporative lagoon system, BEA officially requests termination of WRP LA-000141-03.

\section{BACKGROUND}

The CFA STP was constructed in 1994 and began accepting wastewater in August 1995. The CFA STP replaced an existing sewage treatment facility that operated from 1953 until wastewater was routed to the CFA STP (DOE-ID 2000).

The CFA STP (see Figure 1) is located approximately five miles north of the Idaho National Laboratory (INL) Site's southern boundary and southeast of the CFA, which is about 50 miles west of Idaho Falls in Butte County, Idaho. The STP is approximately 2,200 ft downgradient of the nearest drinking water well and 4,000 ft north of Highway 26. The wastewater LAA is approximately 2,200 ft from the nearest inhabited building.

As shown in Figure 1, the STP consists of:

- A 1.7-acre partial-mix, aeration lagoon (Lagoon 1)

- A 10.3-acre facultative lagoon (Lagoon 2)

- A 0.5-acre polishing lagoon (Lagoon 3) 
- A 73.5-acre wastewater LAA consisting of desert steppe and crested wheatgrass vegetative communities

- A computerized center-pivot, sprinkler irrigation system. 


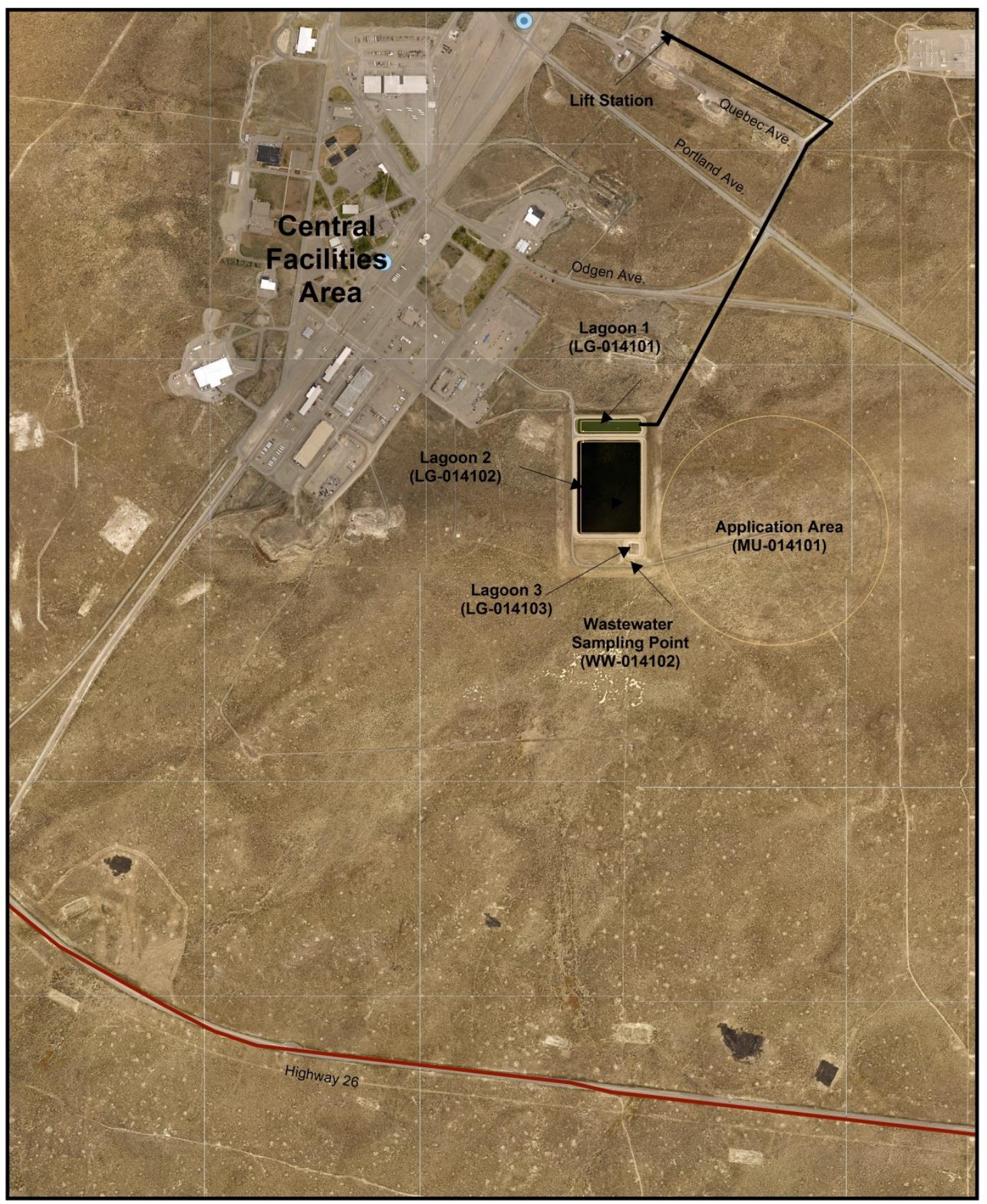

\section{Legend}

Project:
Map Requestor: Mike Lewis

Map Requestor. Mike Lew

GIS Analyst. Kara Cafterty
Date Drawn: 9/21/2017

Path: Z:ProjectsIINLICFA
File Name: CFA_2017 STF_dry.mxd

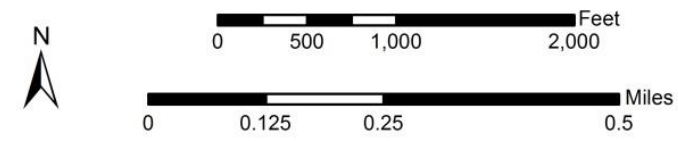

Potable Water Well
U.S. Highway
STP Boundary

Figure 1. Map showing location of the Central Facilities Area Sewage Treatment Plant. 
A 350 gallons per minute pump moves wastewater from the polishing lagoon to the center-pivot sprinkler system, which waters the LAA at low pressure (approximately $30 \mathrm{lbs} / \mathrm{in}^{2}$ ) to minimize aerosols and spray drift.

The design capacity of the CFA STP is 250,000 gallons per day. Currently, the average daily flow is less than 30,000 gallons per day. Due to significantly reduced wastewater discharges to the CFA STP, wastewater has not been land applied since 2011. Because wastewater has not been land applied for several years, future use of the CFA STP was evaluated. A determination was made to decommission Lagoon 3, close the LAA, and terminate coverage under the WRP.

Seepage testing of the three CFA STP wastewater lagoons was performed between August 26, 2014, and September 22, 2014. Seepage rates from Lagoons 1 and 2 were below the 0.25 inches/day requirement; however, Lagoon 3 was above the 0.25 inches/day (Miller 2014). Lagoon 3 was removed from service based on the seepage test results.

\section{CLOSURE PLAN ACTIVITIES}

The closure plan (Miller 2016a) identified the following activities:

- Remove the sludge in Lagoon 3 and place it in Lagoon 2.

- Puncture the Lagoon 3 liner to prevent ponding of storm water and becoming a source for vectors.

- Characterize the soil/liner in Lagoon 3 to determine whether further characterization and/or remediation will be required under the Comprehensive Environmental Response, Compensation, and Liability Act (CERCLA).

- Based on the results from the soil/liner sampling, determine whether additional sampling will be required for the LAA.

- Install a permanent cap on the inlet piping to Lagoon 3.

The closure plan indicated that the first activity would be to remove the sludge from Lagoon 3 and place it into Lagoon 2 for further treatment and then puncture the soil/liner to prevent vector attraction from ponding water. However, because of concerns with not being able to collect representative soil/liner samples due to the soil/liner being disturbed by the heavy equipment tires/tracks and purposely puncturing the soil/liner, characterization samples were collected prior to the other work being performed.

\subsection{Characterization Sampling}

The field sampling plan (FSP) and the Quality Assurance Project Plan (QAPP) for Closure of the CFA STP Lagoon 3 and LAA were submitted (Miller 2016b) to DEQ for review. Comments were received on the QAPP from DEQ on October 13, 2016 (Rackow 2016b). The revised QAPP was submitted to DEQ on November 8, 2016 (Miller 2016c).

The FSP and the QAPP comprise the sampling and analysis plan (SAP) for this effort. Data collected under the SAP was used to evaluate risk of the lagoon and the LAA associated with the CFA STP.

Samples were collected on November 10, 2016 by Portage, INC, and submitted to GEL Laboratories, LLC (GEL), under full chain of custody. Once the sample results/data packages were received from GEL, data validation was performed by Portage, INC.

\subsubsection{Sampling Design}

The sampling design was systematic random sampling, which ensured even coverage of the soil/liner. The sample locations were determined using a systematic diamond grid with locations spaced $25 \mathrm{ft}$ apart horizontally and vertically. A random-number generator was used to determine the location of the first point in the grid, while the rest of the grid was laid out according to the location of that point. This 
ensured that sample locations were random even though the grid was systematic. Fourteen sampling locations were selected and samples were collected at each of those points. Figure 2 shows the layout of the samples on the liner.

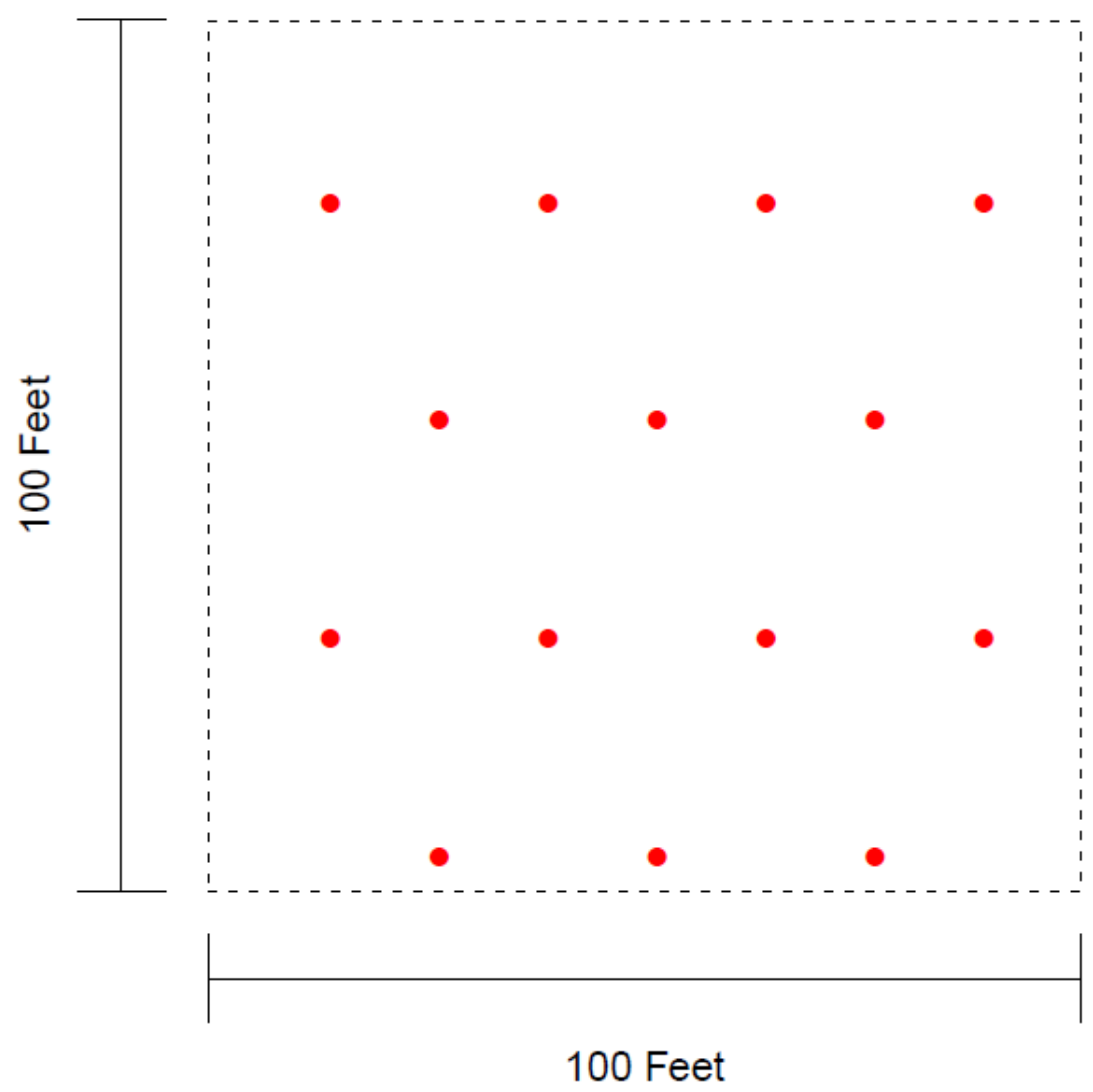

Figure 2. Illustration of the sampling design for Lagoon 3.

\subsubsection{Data Summary}

This section shows the numerical summary statistics for the soil/liner data. 
Table 1 lists the analytes that were measured in the soil and identifies those that were detected and those that were not detected. Ten of the analytes were not detected in any of the samples. 
Table 1. Detected and undetected analytes from the Lagoon 3 soil/liner sampling event.

\begin{tabular}{|c|c|c|}
\hline \multicolumn{3}{|c|}{ Detected Analytes } \\
\hline Arsenic & Copper & Selenium \\
\hline Barium & Lead & Silver \\
\hline Beryllium & Manganese & Methylene chloride $^{\mathrm{a}}$ \\
\hline Cadmium & Mercury & \\
\hline Chromium & Nickel & \\
\hline \multicolumn{3}{|c|}{ Undetected Analytes } \\
\hline Thallium & Tritium & Toluene \\
\hline Cesium-137 & 1,4-Dichlorobenzene & Xylenes (total) \\
\hline Iodine-129 & Benzene & \\
\hline Strontium-90 & Ethylbenzene & \\
\hline
\end{tabular}

Table 2 shows the summary statistics for the detected analytes. The summary statistics that were calculated for the detected constituents were measures of center (mean and median), measures of spread (standard deviation), and the Shapiro-Wilk test to determine if the data followed a normal distribution.

Table 2. Summary statistics for analytes detected in the Lagoon 3 soil/liner samples.

\begin{tabular}{|l|c|c|c|c|c|c|}
\hline \multicolumn{1}{|c|}{ Analyte } & $\begin{array}{c}\text { Number of } \\
\text { Samples }\end{array}$ & $\begin{array}{c}\text { Number of } \\
\text { Detections }\end{array}$ & $\begin{array}{c}\text { Are Data } \\
\text { Normal? }\end{array}$ & $\begin{array}{c}\text { Median } \\
(\mathbf{m g} / \mathbf{k g})\end{array}$ & $\begin{array}{c}\text { Mean } \\
(\mathbf{m g} / \mathbf{k g})\end{array}$ & $\begin{array}{c}\text { Standard } \\
\text { Deviation } \\
(\mathbf{m g} / \mathbf{k g})\end{array}$ \\
\hline Arsenic & 14 & 14 & Yes & 5.02 & 5.07 & 1.39 \\
\hline Barium & 14 & 14 & Yes & 199 & 204 & 20.4 \\
\hline Beryllium & 14 & 14 & Yes & 1.435 & 1.43 & 0.0435 \\
\hline Cadmium & 14 & 14 & No & 0.384 & 0.412 & 0.0941 \\
\hline Chromium & 14 & 14 & No & 26.2 & 26.4 & 0.960 \\
\hline Copper & 14 & 14 & Yes & 32.4 & 33.0 & 3.66 \\
\hline Lead & 14 & 14 & Yes & 17.7 & 17.9 & 1.29 \\
\hline Manganese & 14 & 14 & No & 291 & 305 & 92.9 \\
\hline Mercury & 14 & 14 & No & 0.0179 & 0.0362 & 0.0607 \\
\hline Nickel & 14 & 14 & No & 23.1 & 23.7 & 1.75 \\
\hline Selenium & 14 & 14 & Yes & 1.44 & 1.45 & 0.215 \\
\hline Silver & 14 & 14 & Yes & 0.743 & 0.742 & 0.0664 \\
\hline
\end{tabular}

\subsection{Comparison to Screening Levels}

The action levels for this sampling effort are a series of screening levels. Table 3 compares the analyte maximum sample result concentration with applicable screening levels.

The first step to eliminate analytes from further concern, the maximum measured concentration for each analyte was compared to the INL Site soil background level (see Table 3). If an analyte is less than the INL Site soil background level for all samples, it is considered sufficient for determining that analyte is within safe levels and further screening is not necessary. If the anlayte concentration was above the applicable INL Site soil background level or a background level did not exist, the analyte concentrations were then compared to the Resource Conservation and Recovery Act (RCRA) Toxicity Characteristic Leaching Procedure (TCLP) and CERCLA Residential and Ecological screening levels. If the analyte concentration was below the RCRA and CERCLA screening levels, it was considered safe and no further screening was necessary. 
With the exception of copper, lead, manganese, selenium, and thallium, all other analytes screened out based on the above criteria. Copper, lead, manganese, selenium, and thallium were above both the applicable CERCLA ecological screening levels (ESLs) and the INL Site soil background levels. For thallium, all sample results were below the laboratory instruments minimum detection level. However, the minimum detection level was above the ESL and the INL Site soil background level. Although thallium is not expected to be above the screening levels, it is discussed below with the other four metals.

\subsection{Summary Information for Copper, Lead, Manganese, Selenium, and Thallium}

Copper - Copper was detected in all 14 samples. The sample concentrations ranged from $27.6 \mathrm{mg} / \mathrm{kg}$ to $40.5 \mathrm{mg} / \mathrm{kg}$ with a mean of $33 \mathrm{mg} / \mathrm{kg}$ (see Table 2). All sample results were above the INL Site soil background level of $22 \mathrm{mg} / \mathrm{kg}$. One sample result was below the ESL concentration of $28 \mathrm{mg} / \mathrm{L}$. For comparison, soil background concentrations in the western U.S. range from approximately $15 \mathrm{mg} / \mathrm{kg}$ to $55 \mathrm{mg} / \mathrm{kg}$, according to the U.S. Environmental Protection Agency (EPA 2007a).

Copper is an essential micronutrient in both plants and animals. In animals, copper is essential for hemoglobin formation, carbohydrate metabolism, catecholamine biosynthesis, and cross-linking of collagen, elastin, and hair keratin (EPA 2007a).

Lead - Lead was detected in all 14 samples. The sample concentrations ranged from $15.9 \mathrm{mg} / \mathrm{kg}$ to $20.9 \mathrm{mg} / \mathrm{kg}$ with a mean of $17.9 \mathrm{mg} / \mathrm{kg}$ (see Table 2). Two sample results were below the INL Site soil background level of $17 \mathrm{mg} / \mathrm{kg}$ while 12 were above. All 14 sample results were above the ESL of $11 \mathrm{mg} / \mathrm{kg}$. For comparison, soil background concentrations in the western U.S. range from approximately $8 \mathrm{mg} / \mathrm{kg}$ to $35 \mathrm{mg} / \mathrm{kg}$ (EPA 2007b).

Lead is not considered an essential element in plants or animals. In plants, lead inhibits growth, reduces photosynthesis, interferes with cell division and respiration, reduces water absorption, and assists in transpiration. In animals, lead interferes with the synthesis of heme (EPA 2007b), which is commonly known as a component of hemoglobin.

Manganese - Of the 14 samples collected and analyzed for manganese, only one sample result $(610 \mathrm{mg} / \mathrm{kg}$ ) was above the INL Site soil background level of $490 \mathrm{mg} / \mathrm{L}$. The sample concentrations ranged from $233 \mathrm{mg} / \mathrm{kg}$ to $610 \mathrm{mg} / \mathrm{kg}$ with a mean value of $305 \mathrm{mg} / \mathrm{kg}$ (see Table 2). Soil background concentrations in the U.S. range from approximately $40 \mathrm{mg} / \mathrm{kg}$ to $900 \mathrm{mg} / \mathrm{kg}$ with a mean of $330 \mathrm{mg} / \mathrm{kg}$. The ESL of $220 \mathrm{mg} / \mathrm{kg}$ is less than the fifth percentile of reported background soil concentrations in the western U.S. (EPA 2007c).

Manganese is one of the most abundant trace elements on the Earth's surface and is an essential micronutrient for both plants and animals.

Selenium - Selenium was detected in all 14 samples. The sample concentrations ranged from $0.959 \mathrm{mg} / \mathrm{kg}$ to $1.78 \mathrm{mg} / \mathrm{kg}$ with a mean of $1.45 \mathrm{mg} / \mathrm{kg}$ (see Table 2). All sample results were above the INL Site soil background level of $0.22 \mathrm{mg} / \mathrm{kg}$ and the ESL of $0.52 \mathrm{mg} / \mathrm{kg}$ (EPA 2007d). Soils in the U.S. have selenium concentrations ranging from less than $0.1 \mathrm{mg} / \mathrm{kg}$ to $4.4 \mathrm{mg} / \mathrm{kg}$ (CAST 1994). United States Geological Survey (USGS 2017) data shows concentrations of selenium in Butte County soils ranging from $0.102 \mathrm{mg} / \mathrm{kg}$ to $1.468 \mathrm{mg} / \mathrm{kg}$.

Selenium is a naturally occurring element found in all environmental media and is an essential micronutrient for animals, although it is toxic in large doses (EPA 2007d). Certain plant species require higher levels of selenium and can be used as indicators of high selenium content in the soil.

Thallium - Thallium was not detected in any of the samples. However, the detection limit $(<0.639 \mathrm{mg} / \mathrm{kg}$ ) was above the INL Site soil background concentration of $0.43 \mathrm{mg} / \mathrm{kg}$ and the ESL of 
$0.1 \mathrm{mg} / \mathrm{kg}$ (DOE-ID 1999). In soils, thallium concentrations typically range from $0.1 \mathrm{mg} / \mathrm{kg}$ to $1.0 \mathrm{mg} / \mathrm{kg}$ (EPA 2009).

Thallium is a toxic heavy metallic element that exists in the environment mainly combined with other elements (e.g., primarily oxygen, sulfur, and the halogens) in inorganic compounds. Thallium is quite stable in the environment, since it is neither transformed nor biodegraded. 
Table 3. Comparison of data to background and screening levels associated with the closure of Lagoon 3.

\begin{tabular}{|c|c|c|c|c|c|c|}
\hline Analyte & $\begin{array}{c}\text { Maximum } \\
\text { Sample } \\
\text { Concentration }\end{array}$ & $\begin{array}{c}\text { INL Site Soil } \\
\text { Background } \\
\text { Level }^{\mathrm{a}}\end{array}$ & $\begin{array}{c}\text { RCRA TCLP } \\
\text { Screening Level }^{\text {b }}\end{array}$ & $\begin{array}{c}\text { CERCLA } \\
\text { Residential Soil } \\
\text { Screening Level }^{\mathrm{c}}\end{array}$ & $\begin{array}{c}\text { CERCLA } \\
\text { Ecological } \\
\text { Screening Level }^{\mathbf{c}}\end{array}$ & $\begin{array}{l}\text { RCRA or } \\
\text { CERCLA } \\
\text { Screening Level } \\
\text { Exceeded? } \\
\end{array}$ \\
\hline Metals & $(\mathrm{mg} / \mathrm{kg})$ & $(\mathrm{mg} / \mathrm{kg})$ & $(\mathrm{mg} / \mathrm{kg})$ & $(\mathrm{mg} / \mathrm{kg})$ & $(\mathrm{mg} / \mathrm{kg})$ & \\
\hline Arsenic & 8.46 & 5.8 & 100 & 21.6 & 18 & No \\
\hline Barium & 249 & 300 & 2000 & 15000 & 330 & No \\
\hline Beryllium & 1.53 & 1.8 & $\mathrm{NA}^{\mathrm{d}}$ & $160^{\mathrm{e}}$ & NA & No \\
\hline Cadmium & 0.697 & 2.2 & 20 & 70 & 0.36 & $\begin{array}{c}\text { Yes }^{f} \\
\text { Ecological }\end{array}$ \\
\hline Chromium & 29.0 & 33 & 100 & 28000 & 26.0 & $\begin{array}{c}\text { Yes }^{f} \\
\text { Ecological }\end{array}$ \\
\hline Copper & 40.5 & 22 & NA & 3100 & 28 & $\begin{array}{c}\text { Yes } \\
\text { Ecological }\end{array}$ \\
\hline Lead & 20.9 & 17 & 100 & 400 & 11 & $\begin{array}{c}\text { Yes } \\
\text { Ecological }\end{array}$ \\
\hline Manganese & 610 & 490 & NA & 1800 & 220 & $\begin{array}{c}\text { Yes } \\
\text { Ecological }\end{array}$ \\
\hline Mercury & 0.246 & 0.05 & 4 & 4.3 & 8.4 & No \\
\hline Nickel & 29.0 & 35 & NA & 1500 & 38.0 & No \\
\hline Selenium & 1.78 & 0.22 & 20 & 390 & 0.52 & $\begin{array}{c}\text { Yes } \\
\text { Ecological }\end{array}$ \\
\hline Silver & 0.826 & NA & 100 & 390 & 4.2 & No \\
\hline Thallium $^{\mathrm{g}}$ & $<0.639$ & 0.43 & NA & 6.3 & 0.1 & $\begin{array}{c}\text { Yes }^{\mathrm{h}} \\
\text { Ecological }\end{array}$ \\
\hline Organics & (ug/kg) & (ug/kg) & (ug/kg) & (ug/kg) & (ug/kg) & \\
\hline 1,4-Dichlorobenzene ${ }^{\mathrm{g}}$ & $<0.351$ & NA & NA & $2600^{\mathrm{e}}$ & NA & No \\
\hline Benzene $^{\mathrm{g}}$ & $<0.351$ & NA & NA & $1200^{\mathrm{e}}$ & NA & No \\
\hline Ethylbenzene $^{\mathrm{g}}$ & $<0.351$ & NA & NA & $5800^{\mathrm{e}}$ & NA & No \\
\hline Methylene chloride & 2.27 & NA & NA & $57000^{\mathrm{e}}$ & NA & No \\
\hline Toluene $^{\mathrm{g}}$ & $<0.351$ & NA & NA & $4900000^{\mathrm{e}}$ & NA & No \\
\hline Xylenes (total) ${ }^{\mathrm{g}}$ & $<1.05$ & NA & NA & $580000^{\mathrm{e}}$ & NA & No \\
\hline
\end{tabular}




\begin{tabular}{|c|c|c|c|c|c|c|}
\hline Analyte & $\begin{array}{c}\text { Maximum } \\
\text { Sample } \\
\text { Concentration }\end{array}$ & $\begin{array}{l}\text { INL Site Soil } \\
\text { Background }^{\text {Level }^{\mathbf{a}}}\end{array}$ & $\begin{array}{c}\text { RCRA TCLP } \\
\text { Screening Level }^{\text {b }}\end{array}$ & $\begin{array}{c}\text { CERCLA } \\
\text { Residential Soil } \\
\text { Screening Level }^{\mathrm{c}}\end{array}$ & $\begin{array}{c}\text { CERCLA } \\
\text { Ecological } \\
\text { Screening Level }^{\mathrm{c}}\end{array}$ & $\begin{array}{c}\text { RCRA or } \\
\text { CERCLA } \\
\text { Screening Level } \\
\text { Exceeded? } \\
\end{array}$ \\
\hline Radionuclides & $(\mathrm{pCi} / \mathrm{g})$ & $(\mathrm{pCi} / \mathrm{g})$ & $(\mathrm{pCi} / \mathrm{g})$ & $(\mathrm{pCi} / \mathrm{g})$ & $(\mathrm{pCi} / \mathrm{g})$ & \\
\hline Cesium-137 & $<0.0528$ & 0.82 & NA & 6 & 4950 & No \\
\hline Iodine- $129^{\mathrm{g}}$ & $<1.18$ & $\mathrm{NA}$ & NA & $3.3^{\mathrm{e}}$ & NA & No \\
\hline Strontium-90 $90^{\mathrm{g}}$ & $<1.85$ & 0.49 & NA & $23.1^{\mathrm{e}}$ & 3340 & No \\
\hline Tritium $^{\mathrm{g}}$ & $<4.49$ & $\mathrm{NA}$ & NA & 23 & NA & No \\
\hline \multicolumn{7}{|c|}{$\begin{array}{l}\text { a. Background Dose Equivalent Rates and Surficial Soil Metal and Radionuclide Concentrations for the Idaho National Engineering Laboratory (Rood, Harris, and White } \\
\text { 1996). } \\
\text { b. Screening levels } 20 \text { times the value listed in } 40 \text { CFR 261.24, Table 1, "Maximum Concentration of Contaminants for the Toxicity Characteristics." } \\
\text { c. Residential screening levels are } 10-6 \text { risk-based levels or hazard quotient of } 1 \text { taken from Operable Unit 10-08 Remedial Design/Remedial Action Work Plan (DOE-ID } \\
\text { 2010), unless footnoted otherwise. } \\
\text { d. NA = not applicable. } \\
\text { e. The EPA regional screening level (EPA 2015) for 10-6 risk-based level or hazard quotient of 1, whichever is more restrictive. } \\
\text { f. The maximum chromium sample result was over the CERCLA Ecological Screening Level but was below the INL Site Soil Background Level, therefore, no further } \\
\text { characterization is required. } \\
\text { g. Analyte was not detected in any samples. Maximum value listed is the largest detection limit. }\end{array}$} \\
\hline
\end{tabular}




\subsection{Evaluation of Parameters Exceeding Ecological Screening Levels}

Ecological soil screening levels are concentrations of contaminants in the soil that are protective of ecological receptors that commonly come into contact with and/or consume biota that live in or on the soil. The EPA did not design the ESLs to be used as cleanup levels, but they should be used for additional risk assessment (EPA 2007a).

Contaminants that exceeded an ESL were assessed using the Hazard Quotient (HQ) analysis described in the OU-10-04 Remedial Investigation/Feasibility Study, as updated by the OU 10-08 Remedial Investigation/Baseline Risk Assessment (DOE-ID 2008) and the Refined Waste Area Group Ecological Risk Assessments (VanHorn 2013). The HQ is a unitless ratio of dose to toxicity reference value (hazard quotient $[\mathrm{HQ}]=$ dose/toxicity reference value). HQ $>10$ is the adopted point of departure for potential population-level ecological risk at the INL Site (VanHorn 2013). HQs provide essentially a yes or no determination of risk and are therefore well-suited for screening level assessments (EPA 1988).

The analysis determined that the HQ for copper, lead, manganese, and thallium were less than 1 and the HQ for selenium (3.77) was less than 10 (see Table 4). Having an HQ less than 10 indicates the ecological risk is acceptable and thus screened from further evaluation under CERCLA. The following paragraphs are included and support the elimination of these inorganics from being a concern for populations of ecological receptors.

For comparison purposes, Table 5 includes the EPA's 40 CFR 503.13, Table 3, "Pollutant Concentrations," for copper, lead, and selenium. These EPA Pollutant Concentrations are used to determine whether sewage biosolids can be applied to agricultural land, forest, a public contact site, or a reclamation site. As shown in Table 5, the Pollutant Concentrations in sewage sludge that can be applied to agricultural land are significantly higher than the sample results, INL Site soil background, and CERCLA ESLs.

The maximum sample concentration for selenium was $1.78 \mathrm{mg} / \mathrm{kg}$ and exceeded the ESL of $0.52 \mathrm{mg} / \mathrm{kg}$. Selenium also had the highest HQ at 3.77. However, the maximum sample concentration is significantly lower than the EPA level for applying sewage sludge to agricultural land at a concentration of $100 \mathrm{mg} / \mathrm{kg}$ (see Table 5).

Similar to selenium, when comparing the maximum copper and lead sample results to the EPA allowable levels in sewage sludge (see Table 5), the sample results are more than an order of magnitude lower than the EPA levels. 
Table 4. Results of ecological risk evaluation for specific metals.

\begin{tabular}{|l|l|l|l|l|l|l|}
\hline Functional Groups & Copper & Lead & Manganese & Selenium & Thallium & $\begin{array}{l}\text { Maximum } \\
\text { Hazard } \\
\text { Quotient }\end{array}$ \\
\hline $\begin{array}{l}\text { Great Basin } \\
\text { spadefoot toad }\end{array}$ & NA & NA & NA & NA & NA & $\mathbf{0 . 0 0 E + 0 0}$ \\
\hline Mourning dove & $6.42 \mathrm{E}-03$ & $1.10 \mathrm{E}-03$ & $5.11 \mathrm{E}-04$ & $7.23 \mathrm{E}-03$ & $5.47 \mathrm{E}-04$ & $\mathbf{7 . 2 3 E - 0 3}$ \\
\hline Blue-winged teal & $0.00 \mathrm{E}+00$ & $0.00 \mathrm{E}+00$ & $0.00 \mathrm{E}+00$ & $0.00 \mathrm{E}+00$ & $0.00 \mathrm{E}+00$ & $\mathbf{0 . 0 0 E + 0 0}$ \\
\hline Sage sparrow & $1.41 \mathrm{E}-01$ & $6.41 \mathrm{E}-03$ & $1.70 \mathrm{E}-03$ & $2.96 \mathrm{E}-01$ & $1.32 \mathrm{E}-02$ & $\mathbf{2 . 9 6 E - 0 1}$ \\
\hline Ferruginous hawk & $2.43 \mathrm{E}-05$ & $1.10 \mathrm{E}-06$ & $2.93 \mathrm{E}-07$ & $5.10 \mathrm{E}-05$ & $2.27 \mathrm{E}-06$ & $\mathbf{5 . 1 0 E}-\mathbf{0 5}$ \\
\hline Loggerhead shrike & $9.27 \mathrm{E}-03$ & $4.21 \mathrm{E}-04$ & $1.12 \mathrm{E}-04$ & $1.95 \mathrm{E}-02$ & $8.66 \mathrm{E}-04$ & $\mathbf{1 . 9 5 E - 0 2}$ \\
\hline Burrowing owl & $1.76 \mathrm{E}-03$ & $7.99 \mathrm{E}-05$ & $2.12 \mathrm{E}-05$ & $3.70 \mathrm{E}-03$ & $1.65 \mathrm{E}-04$ & $\mathbf{3 . 7 0 E - 0 3}$ \\
\hline $\begin{array}{l}\text { Black-billed } \\
\text { magpie }\end{array}$ & $4.46 \mathrm{E}-03$ & $5.31 \mathrm{E}-04$ & $2.30 \mathrm{E}-04$ & $6.82 \mathrm{E}-03$ & $2.82 \mathrm{E}-04$ & $\mathbf{6 . 8 2 E - 0 3}$ \\
\hline Mule deer & $1.38 \mathrm{E}-03$ & $1.13 \mathrm{E}-04$ & $5.28 \mathrm{E}-04$ & $4.36 \mathrm{E}-03$ & $2.03 \mathrm{E}-04$ & $\mathbf{4 . 3 6 E - 0 3}$ \\
\hline Pygmy rabbit & $4.63 \mathrm{E}-01$ & $3.80 \mathrm{E}-02$ & $1.77 \mathrm{E}-01$ & $1.46 \mathrm{E}+00$ & $6.82 \mathrm{E}-02$ & $\mathbf{1 . 4 6 E + 0 0}$ \\
\hline $\begin{array}{l}\text { Townsend's } \\
\text { western big-eared } \\
\text { bat }\end{array}$ & $2.55 \mathrm{E}-02$ & $5.54 \mathrm{E}-04$ & $1.48 \mathrm{E}-03$ & $1.50 \mathrm{E}-01$ & $4.12 \mathrm{E}-03$ & $\mathbf{1 . 5 0 E - 0 1}$ \\
\hline Coyote & $1.74 \mathrm{E}-06$ & $3.79 \mathrm{E}-08$ & $1.01 \mathrm{E}-07$ & $1.03 \mathrm{E}-05$ & $2.81 \mathrm{E}-07$ & $\mathbf{1 . 0 3 E - 0 5}$ \\
\hline Deer mouse & $5.87 \mathrm{E}-01$ & $3.35 \mathrm{E}-02$ & $1.45 \mathrm{E}-01$ & $2.51 \mathrm{E}+00$ & $5.99 \mathrm{E}-02$ & $\mathbf{2 . 5 1 E + 0 0}$ \\
\hline Sagebrush lizard & NA & NA & NA & NA & NA & $\mathbf{0 . 0 0 E + 0 0}$ \\
\hline Plants & $3.47 \mathrm{E}-01$ & $1.39 \mathrm{E}-02$ & $3.88 \mathrm{E}-01$ & $3.77 \mathrm{E}+00$ & $2.56 \mathrm{E}-02$ & $\mathbf{3 . 7 7 E + 0 0}$ \\
\hline $\begin{array}{l}\text { Grasshoppers, } \\
\text { beetles }\end{array}$ & NA & NA & NA & NA & NA & $\mathbf{0 . 0 0 E + 0 0}$ \\
\hline $\begin{array}{l}\text { Maximum Hazard } \\
\text { Quotient }\end{array}$ & $\mathbf{5 . 8 7 E - 0 1}$ & $\mathbf{3 . 8 0 E - 0 2}$ & $\mathbf{3 . 8 8 E - 0 1}$ & $\mathbf{3 . 7 7 E + 0 0}$ & $\mathbf{6 . 8 2 E - 0 2}$ & $\mathbf{3 . 7 7 E + 0 0}$ \\
\hline a. Hazard Quotient values are unitless. & & & & & \\
\hline
\end{tabular}

Table 5. Comparison of sample maximum concentrations to the Idaho National Laboratory Site soil background levels, Comprehensive Environmental Response, Compensation, and Liability Act ecological screening levels, and the Environmental Protection Agency sewage sludge pollutant concentrations.

\begin{tabular}{|c|c|c|c|c|}
\hline Analyte & $\begin{array}{c}\text { Maximum } \\
\text { Sample } \\
\text { Concentration } \\
(\mathbf{m g} / \mathbf{k g}) \\
\end{array}$ & $\begin{array}{c}\text { INL Site Soil } \\
\text { Background } \\
\text { Level }^{\mathrm{a}} \\
(\mathrm{mg} / \mathrm{kg})\end{array}$ & $\begin{array}{c}\text { CERCLA } \\
\text { Ecological } \\
\text { Screening Level }^{\mathrm{b}} \\
(\mathrm{mg} / \mathrm{kg})\end{array}$ & $\begin{array}{c}\text { Sewage Sludge } \\
\text { Pollutant } \\
\text { Concentration } \\
(\mathrm{mg} / \mathrm{kg})\end{array}$ \\
\hline Copper & 40.5 & 22 & 28 & 1500 \\
\hline Lead & 20.9 & 17 & 11 & 300 \\
\hline Manganese $^{\mathrm{d}}$ & 610 & 490 & 220 & NA \\
\hline Selenium & 1.78 & 0.22 & 0.52 & 100 \\
\hline Thallium $^{\mathrm{e}}$ & $<0.639$ & 0.43 & 0.1 & $\mathrm{NA}$ \\
\hline \multicolumn{5}{|c|}{$\begin{array}{l}\text { a. Background Dose Equivalent Rates and Surficial Soil Metal and Radionuclide Concentrations for the Idaho National } \\
\text { Engineering Laboratory (Rood, Harris, and White 1996). } \\
\text { b. Residential screening levels are 10-6 risk-based levels or hazard quotient of } 1 \text { taken from Operable Unit 10-08 Remedial } \\
\text { Design/Remedial Action Work Plan (DOE-ID 2010). } \\
\text { c. } 40 \text { CFR 503, Standards for the Use or Disposal of Sewage Sludge, Subsection .13, Pollutant Limits, Table 3, Pollutant } \\
\text { Concentrations. } \\
\text { d. Only one sample result was above the ecological screening level. } \\
\text { e. Analyte was not detected in any samples. Maximum value listed is the highest detection limit reported. }\end{array}$} \\
\hline
\end{tabular}




\section{LAGOON 3 CLOSURE ACTIVITIES}

Sludge from CFA STP Lagoon 3 (see Figure 1) was removed and placed in CFA STP Lagoon 2 in August 2017 for additional treatment. It was estimated that 20 cubic yards of sludge was transferred from Lagoon 3 to Lagoon 2. Below is a summary of the closure activities:

August 9, 2017 - Management authorization to begin work was obtained. RadCon completed spot surveys of the bottom of Lagoon 3.

August 10, 2017 - A front end loader and backhoe were able to drive down the riprap near the northwest corner of Lagoon 3 to access the sludge. The front end loader scraped up the sludge from the bottom of the lagoon and piled it in the northeast corner. Once all the sludge was in the pile, the front end loader began picking up the sludge, drove out of the lagoon and dumped the sludge into Lagoon 2. Once all the sludge was removed from Lagoon 3, a water truck being used for dust suppression was used to spray any sludge that had been deposited on the Lagoon 2 riprap into the water in the lagoon. The backhoe punctured the soil/liner, approximately 2 to 3 feet deep, near the southwest corner of Lagoon 3 (see Figure 4).

August 15, 2017 - RadCon completed clearance surveys for the equipment.

August 16, 2017 - Plastic caps were placed on both the primary (see Figure 4) and bypass inlet pipes in Lagoon 3 to prevent any wastewater from entering the lagoon in the future.

August 29, 2017 - The backhoe was brought back in and punctured the Lagoon 3 soil/liner in 3 more places (southeast, northcentral, and northeast) at an approximate depth of 2 to 3 feet.

August 30, 2017 - Laborers transferred sludge that was left on and near the splash guards that could not be picked up by the front end loader into Lagoon 2 using shovels and a bucket. Figure 5 shows Lagoon 3 after all the work had been completed.

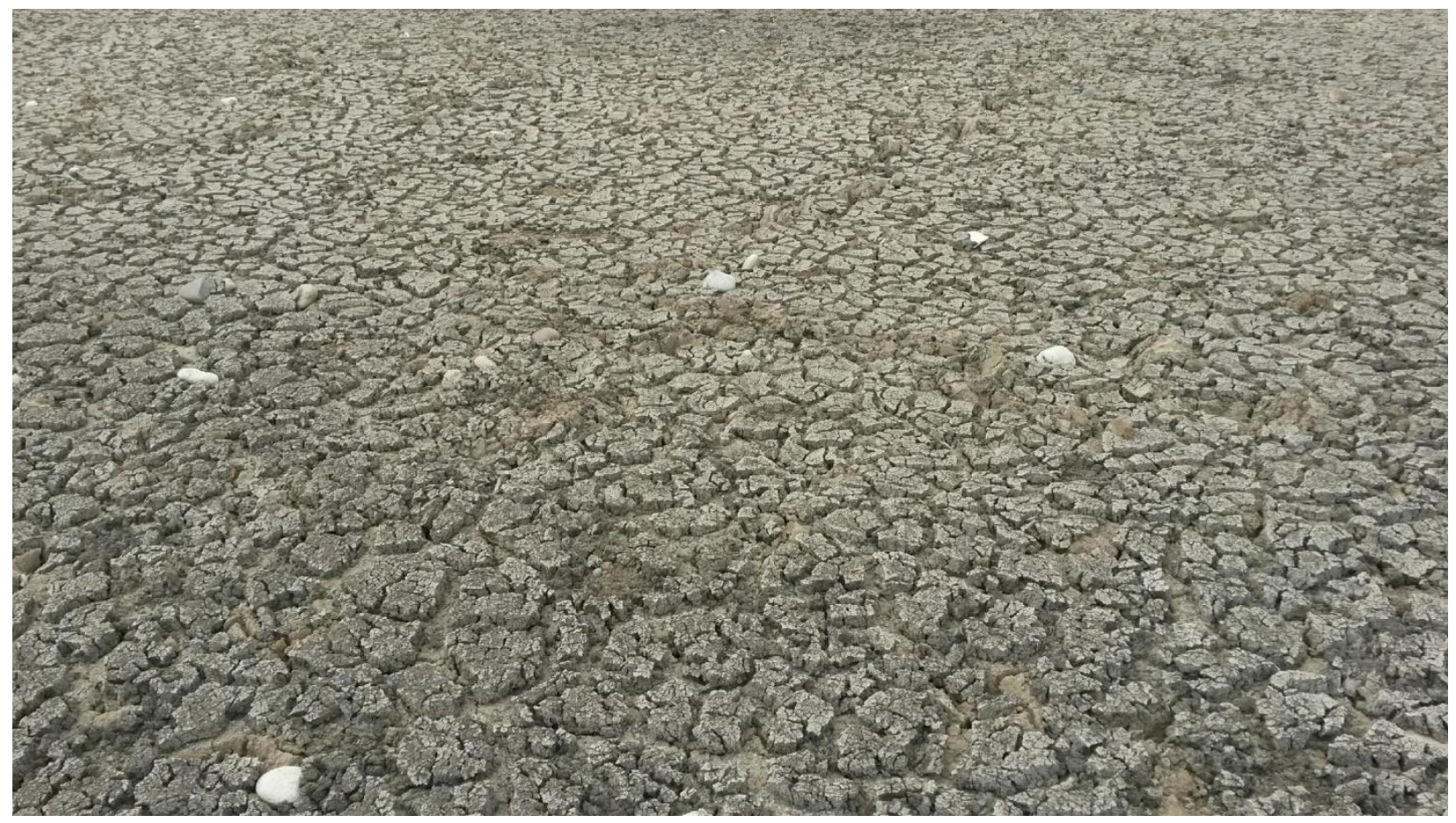

Figure 3. Dried sludge in the bottom of the Central Facilities Area Sewage Treatment Plant Lagoon 3. 


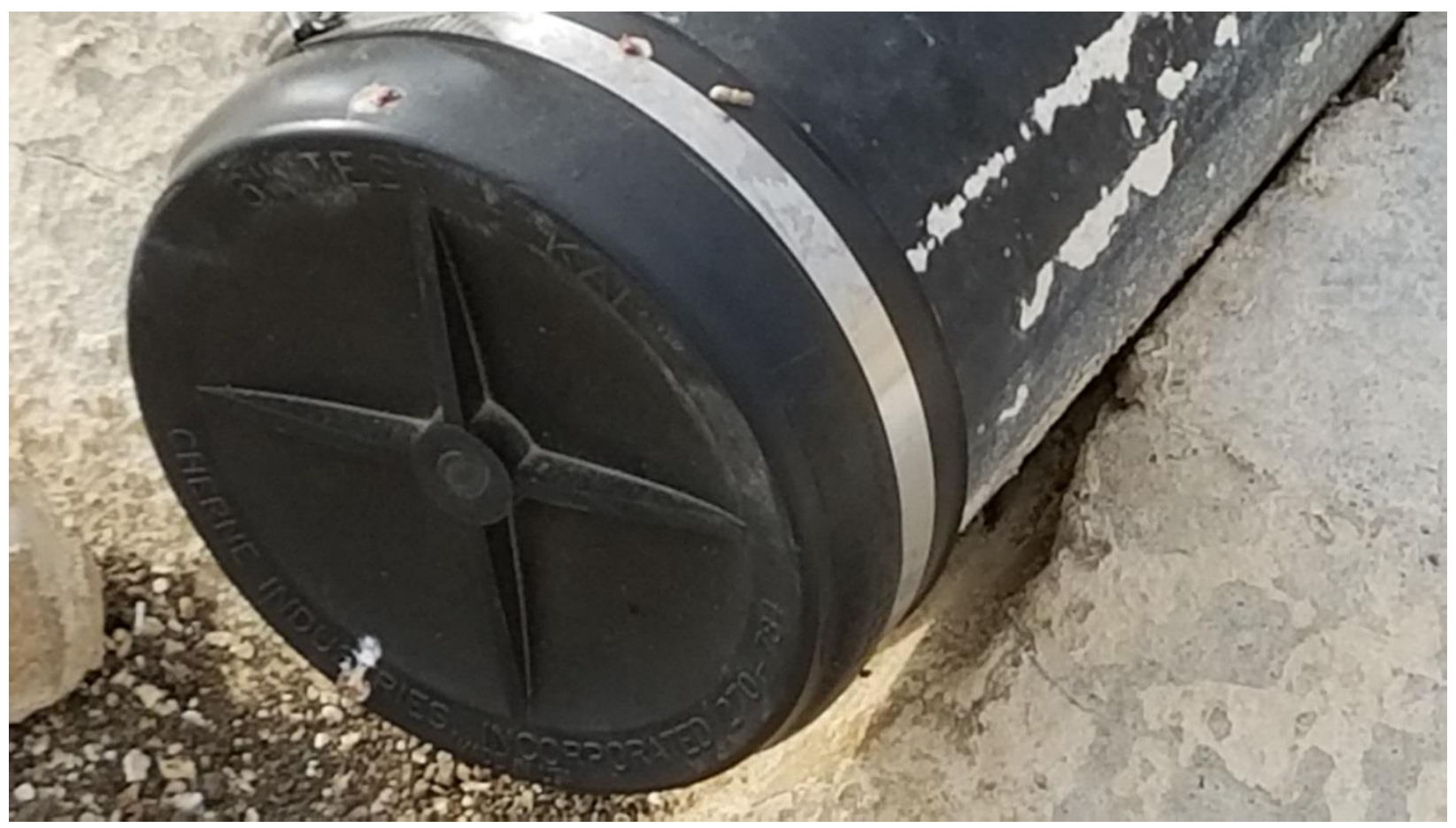

Figure 4. Cap placed on primary inlet pipe.

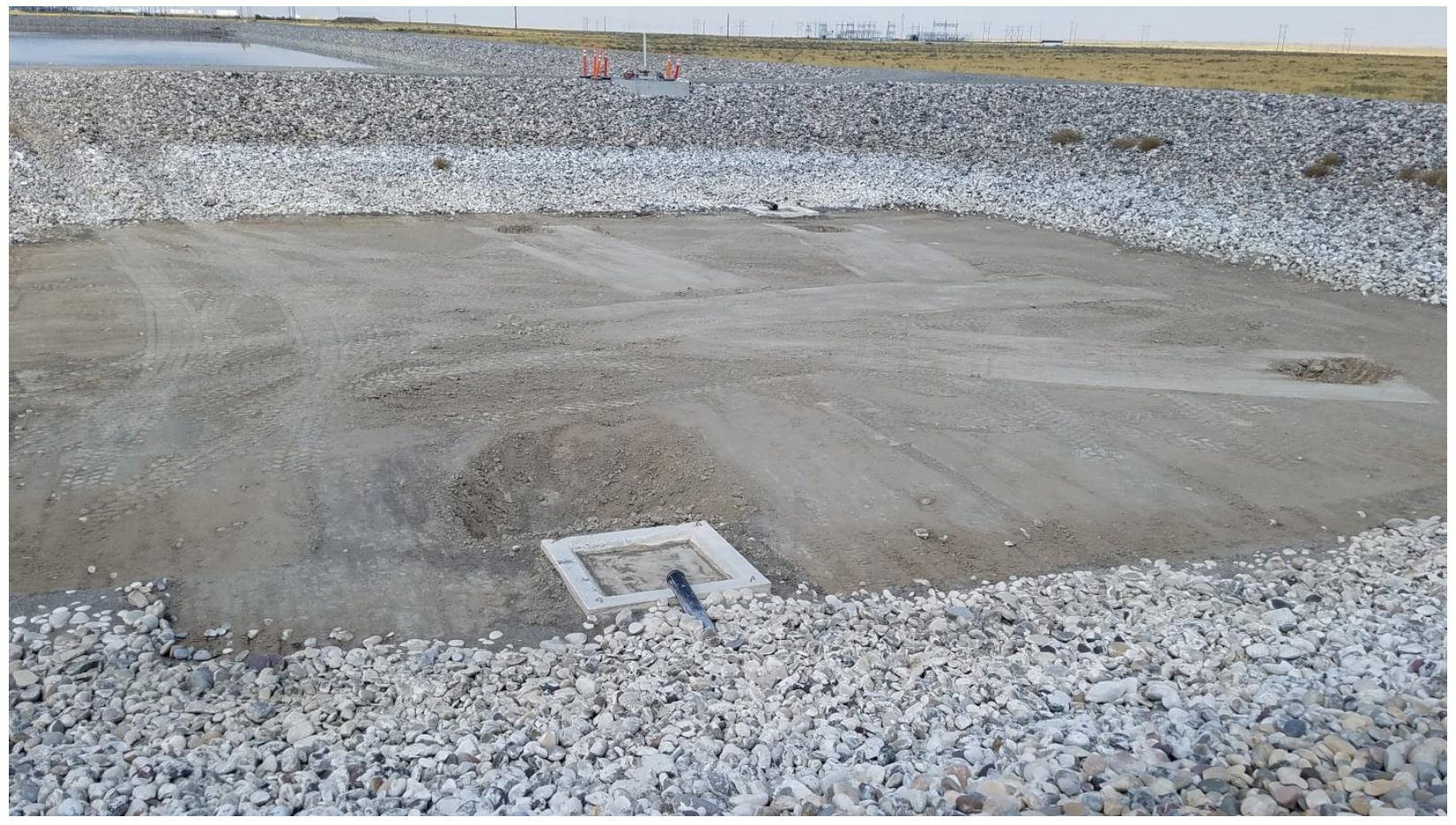

Figure 5. Photo showing Central Facilities Area Sewage Treatment Plant Lagoon 3 after all work was completed. 


\section{Conclusion}

The CFA STP was placed into operation in August 1995. By this time, significant environmental regulations had been enacted by the regulatory agencies that were being implemented at the INL. These restrictions included no RCRA hazardous waste, no PCBs, no petroleum products, etc. New wastewater discharges into the CFA STP had to be reviewed and approved by the INL environmental organization. The regulations and environmental awareness helped ensure the CFA STP lagoons were not contaminated with hazardous materials.

As seen from the sampling data, the majority of contaminants sampled for in the Lagoon 3 soil/liner were below the applicable screening levels. Only copper, lead, manganese, and selenium had detected sample results above both the ESL and the INL Site soil background level. Thallium concentrations were below the laboratory instruments minimum detection level. However, the minimum detection level was above the ESL and INL Site soil background level. Therefore, an HQ analysis was performed on these five metals to further assess the potential impacts to human health and the environment. All five metals were below an HQ of 10, indicating the ecological risk is acceptable.

Although copper, lead, manganese, selenium, and thallium (detection level) were above the INL Site soil background levels, they were within the background range of soils in the U.S. In addition, Table 5 shows that the maximum copper, lead, and selenium concentrations in the soil/liner were significantly less than EPA, 40 CFR 503 concentrations allowed in sewage sludge used for land application.

The work described in the closure plan has been completed. The soil/liner sample results show there are no hazards to human health and the environment. Therefore, both Lagoon 3 and the LAA can be considered closed and the WRP can be terminated. 


\section{REFERENCES}

CAST, 1994, Council for Agricultural Science and Technology, Issue Paper, Number 3, June 1994.

DOE-ID, 1999, Work Plan for Waste Area Group 6 \& 10 (WAG-6 \& WAG-10) Operable Unit (OU)

10-04 Comprehensive Remedial Investigation Feasibility Study (RI/FS), DOE/ID-10554, Rev. 0,

U. S. Department of Energy Idaho Operations Office, April 1999.

DOE-ID, 2000, Final Comprehensive Record of Decision for Central Facilities Area Operable Unit 4-13, DOE/ID-10719, Rev. 2, U. S. Department of Energy Idaho Operations Office, July 2000,

DOE-ID, 2008, Operable Unit 10-08 Sitewide Groundwater and Miscellaneous Sites Remedial Investigation/Risk Assessment, DOE/ID-11332, Rev. 0, U. S. Department of Energy Idaho Operations Office, April 2008.

EPA, 2007a, Ecological Soil Screening Levels for Copper, Interim Final, OSWER Directive 9285.7-68, U. S. Environmental Protection Agency, February 2007, Revision 1.

EPA, 2007b, Ecological Soil Screening Levels for Lead, Interim Final, OSWER Directive 9285.7-70, U. S. Environmental Protection Agency, April 2007.

EPA, 2007c, Ecological Soil Screening Levels for Manganese, Interim Final, OSWER Directive 9285.7-71, U. S. Environmental Protection Agency, April 2007.

EPA, 2007d, Ecological Soil Screening Levels for Selenium, Interim Final, OSWER Directive 9285.7-72, U. S. Environmental Protection Agency, July 2007.

EPA, 2009, Toxicological Review of Thallium and Compounds, In support of summary Information on the Integrated Risk Information System (IRIS), EPA/635/R-08/001F, September 2009.

Lewis, M. G., INL, email to V. Dugger, DOE-ID, et al., December 17, 2014, Meeting with DEQ Concerning CFA STP Closure, CCN 234739.

Lewis, M. G., INL, email to V. Dugger, DOE-ID, et al., February 10, 2016, CFA STP Sewage Sludge Dispsoal Discussion with DEQ, February 4, 2016, CCN 237574.

Miller, T. A., INL, email to T. Rackow, P. E., DEQ, October 16, 2014, Transmittal of the Seepage Test Report for the Central Facilities Area Sewage Treament Plant Lagoon, CCN 234223.

Miller, T. A, INL, email to T. Rackow, P. E., DEQ, February 23, 2015, Idaho National Laboratory Central facilities Area Sewage Treatment Plant Closure Plan for Lagoon \#3 and wastewater Land Application Area, CCN 235243.

Miller, T. A., INL, email to T. Rackow, P. E., DEQ, May 6, 2016a, Central Facilities Area Sewage Treatment Plant Revised Closure Plan for Lagoon 3 and the Land Application Area, and request for Termination of Wastewater Reuse Permit LA-000141-03, CCN 238192.

Miller, T. A., INL, email to T. Rackow, P. E., DEQ, October 6, 2016b, Quality Assurance Project Plan and Field Sampling Plan for Closure of the Central Facilities Area Sewage Treatment Plant Lagoon 3 and Land Application Area, CCN 239147.

Miller, T. A., INL, email to T. Rackow, P. E., DEQ, October 27 2016c, Quality Assurance Project Plan for Closure of the Central Facilities Area Sewage Treatment Plant Lagoon 3 and Land Application Area, Revision 1, CCN 239292. 
Neher, E., DEQ, email to R. V. Furstenau, DOE_ID and D. E. Coburn, INL, March 17, 2010, LA000141-03 INL CFA Sewage Treatment Facility, Final Wastewater Reuse Permit, CCN 220416.

Rackow, T., P. E., DEQ, email to T. A. Miller, INL, June 16, 2015, LA-000141-03 INL CFA Sewage Treatment Plant Lagoon \#3 Closure and Reuse Permit Termination Request, CCN 236044.

Rackow, T., P. E., DEQ, email to T. A. Miller, INL, July 5, 2016a, LA-000141-03 INL CFA Sewage Treatment Plant Lagoon \#3 Closure Plan Approval, CCN 238560.

Rackow, T., P. E., DEQ, email to T. Miller, INL, October 13, 2016b, LA-000141-03 INL CFA Sewage Treatment Plant Lagoon \#3 Quality Assurance Project Plan and Field Sampling Plan Review, CCN 239234.

USGS, Mineral Resources On-Line Spatial Data, Accessed on May 23, 2017.

VanHorn, R. L., 2013, Refined Waste Area Group Ecological Risk Assessments at the INL Site, RPT-969, Rev. 1, Idaho Cleanup Project, August 2013. 


\section{Appendix A}

Soil/Liner Sample Data from Central Facilities Area Sewage Treatment Plant Lagoon 3 
Table A-1. Central Facilities Area Sewage Treatment Plant Lagoon 3 soil/liner metals sample data.

\begin{tabular}{|c|c|c|c|c|c|c|c|}
\hline Sample ID & $\begin{array}{l}\text { Lab Sample } \\
\text { ID }\end{array}$ & Analyte Name & Detection Limit & Result & Units & $\begin{array}{c}\text { Lab } \\
\text { Qualifiers }\end{array}$ & $\begin{array}{l}\text { Validation } \\
\text { Flag }\end{array}$ \\
\hline CFAN160011-Liner Sample 1 & 410494001 & Arsenic & 0.616 & 4.91 & $\mathrm{mg} / \mathrm{kg}$ & & \\
\hline CFAN160012-Liner Sample 2 & 410494002 & Arsenic & 0.61 & 3.89 & $\mathrm{mg} / \mathrm{kg}$ & & \\
\hline CFAN160013-Liner Sample 3 & 410494003 & Arsenic & 0.637 & 5.64 & $\mathrm{mg} / \mathrm{kg}$ & & \\
\hline CFAN160014-Liner Sample 4 & 410494004 & Arsenic & 0.599 & 5.91 & $\mathrm{mg} / \mathrm{kg}$ & & \\
\hline CFAN160015-Liner Sample 5 & 410494005 & Arsenic & 0.618 & 6.24 & $\mathrm{mg} / \mathrm{kg}$ & & \\
\hline CFAN160016-Liner Sample 6 & 410494006 & Arsenic & 0.578 & 5.13 & $\mathrm{mg} / \mathrm{kg}$ & & \\
\hline CFAN160017-Liner Sample 7 & 410494007 & Arsenic & 0.617 & 2.95 & $\mathrm{mg} / \mathrm{kg}$ & $\mathrm{B}$ & \\
\hline CFAN160018-Liner Sample 8 & 410494008 & Arsenic & 0.596 & 3.59 & $\mathrm{mg} / \mathrm{kg}$ & & \\
\hline CFAN160019-Liner Sample 9 & 410494009 & Arsenic & 0.6 & 3.93 & $\mathrm{mg} / \mathrm{kg}$ & & \\
\hline CFAN160020-Liner Sample 10 & 410494010 & Arsenic & 0.595 & 5.97 & $\mathrm{mg} / \mathrm{kg}$ & & \\
\hline CFAN160021-Liner Sample 11 & 410494011 & Arsenic & 0.629 & 8.46 & $\mathrm{mg} / \mathrm{kg}$ & & \\
\hline CFAN160022-Liner Sample 12 & 410494012 & Arsenic & 0.592 & 4.35 & $\mathrm{mg} / \mathrm{kg}$ & & \\
\hline CFAN160023-Liner Sample 13 & 410494013 & Arsenic & 0.639 & 4.52 & $\mathrm{mg} / \mathrm{kg}$ & & \\
\hline CFAN160024-Liner Sample 14 & 410494014 & Arsenic & 0.601 & 5.54 & $\mathrm{mg} / \mathrm{kg}$ & & \\
\hline CFAN160011-Liner Sample 1 & 410494001 & Barium & 0.123 & 189 & $\mathrm{mg} / \mathrm{kg}$ & & \\
\hline CFAN160012-Liner Sample 2 & 410494002 & Barium & 0.122 & 184 & $\mathrm{mg} / \mathrm{kg}$ & & \\
\hline CFAN160013-Liner Sample 3 & 410494003 & Barium & 0.127 & 209 & $\mathrm{mg} / \mathrm{kg}$ & & \\
\hline CFAN160014-Liner Sample 4 & 410494004 & Barium & 0.12 & 219 & $\mathrm{mg} / \mathrm{kg}$ & & \\
\hline CFAN160015-Liner Sample 5 & 410494005 & Barium & 0.124 & 210 & $\mathrm{mg} / \mathrm{kg}$ & & \\
\hline CFAN160016-Liner Sample 6 & 410494006 & Barium & 0.116 & 195 & $\mathrm{mg} / \mathrm{kg}$ & & \\
\hline CFAN160017-Liner Sample 7 & 410494007 & Barium & 0.123 & 182 & $\mathrm{mg} / \mathrm{kg}$ & & \\
\hline CFAN160018-Liner Sample 8 & 410494008 & Barium & 0.119 & 199 & $\mathrm{mg} / \mathrm{kg}$ & & \\
\hline CFAN160019-Liner Sample 9 & 410494009 & Barium & 0.12 & 233 & $\mathrm{mg} / \mathrm{kg}$ & & \\
\hline CFAN160020-Liner Sample 10 & 410494010 & Barium & 0.119 & 214 & $\mathrm{mg} / \mathrm{kg}$ & & \\
\hline CFAN160021-Liner Sample 11 & 410494011 & Barium & 0.126 & 249 & $\mathrm{mg} / \mathrm{kg}$ & & \\
\hline CFAN160022-Liner Sample 12 & 410494012 & Barium & 0.118 & 175 & $\mathrm{mg} / \mathrm{kg}$ & & \\
\hline CFAN160023-Liner Sample 13 & 410494013 & Barium & 0.128 & 196 & $\mathrm{mg} / \mathrm{kg}$ & & \\
\hline CFAN160024-Liner Sample 14 & 410494014 & Barium & 0.12 & 199 & $\mathrm{mg} / \mathrm{kg}$ & & \\
\hline CFAN160011-Liner Sample 1 & 410494001 & Beryllium & 0.123 & 1.41 & $\mathrm{mg} / \mathrm{kg}$ & & \\
\hline CFAN160012-Liner Sample 2 & 410494002 & Beryllium & 0.122 & 1.43 & $\mathrm{mg} / \mathrm{kg}$ & & \\
\hline CFAN160013-Liner Sample 3 & 410494003 & Beryllium & 0.127 & 1.41 & $\mathrm{mg} / \mathrm{kg}$ & & \\
\hline CFAN160014-Liner Sample 4 & 410494004 & Beryllium & 0.12 & 1.37 & $\mathrm{mg} / \mathrm{kg}$ & & \\
\hline
\end{tabular}




\begin{tabular}{|c|c|c|c|c|c|c|c|}
\hline Sample ID & $\begin{array}{c}\text { Lab Sample } \\
\text { ID } \\
\end{array}$ & Analyte Name & Detection Limit & Result & Units & $\begin{array}{c}\text { Lab } \\
\text { Qualifiers }\end{array}$ & $\begin{array}{c}\text { Validation } \\
\text { Flag }\end{array}$ \\
\hline CFAN160015-Liner Sample 5 & 410494005 & Beryllium & 0.124 & 1.39 & $\mathrm{mg} / \mathrm{kg}$ & & \\
\hline CFAN160016-Liner Sample 6 & 410494006 & Beryllium & 0.116 & 1.44 & $\mathrm{mg} / \mathrm{kg}$ & & \\
\hline CFAN160017-Liner Sample 7 & 410494007 & Beryllium & 0.123 & 1.46 & $\mathrm{mg} / \mathrm{kg}$ & & \\
\hline CFAN160018-Liner Sample 8 & 410494008 & Beryllium & 0.119 & 1.44 & $\mathrm{mg} / \mathrm{kg}$ & & \\
\hline CFAN160019-Liner Sample 9 & 410494009 & Beryllium & 0.12 & 1.45 & $\mathrm{mg} / \mathrm{kg}$ & & \\
\hline CFAN160020-Liner Sample 10 & 410494010 & Beryllium & 0.119 & 1.49 & $\mathrm{mg} / \mathrm{kg}$ & & \\
\hline CFAN160021-Liner Sample 11 & 410494011 & Beryllium & 0.126 & 1.53 & $\mathrm{mg} / \mathrm{kg}$ & & \\
\hline CFAN160022-Liner Sample 12 & 410494012 & Beryllium & 0.118 & 1.39 & $\mathrm{mg} / \mathrm{kg}$ & & \\
\hline CFAN160023-Liner Sample 13 & 410494013 & Beryllium & 0.128 & 1.45 & $\mathrm{mg} / \mathrm{kg}$ & & \\
\hline CFAN160024-Liner Sample 14 & 410494014 & Beryllium & 0.12 & 1.39 & $\mathrm{mg} / \mathrm{kg}$ & & \\
\hline CFAN160011-Liner Sample 1 & 410494001 & Cadmium & 0.123 & 0.364 & $\mathrm{mg} / \mathrm{kg}$ & $\mathrm{B}$ & \\
\hline CFAN160012-Liner Sample 2 & 410494002 & Cadmium & 0.122 & 0.395 & $\mathrm{mg} / \mathrm{kg}$ & $\mathrm{B}$ & \\
\hline CFAN160013-Liner Sample 3 & 410494003 & Cadmium & 0.127 & 0.372 & $\mathrm{mg} / \mathrm{kg}$ & $\mathrm{B}$ & \\
\hline CFAN160014-Liner Sample 4 & 410494004 & Cadmium & 0.12 & 0.435 & $\mathrm{mg} / \mathrm{kg}$ & $\mathrm{B}$ & \\
\hline CFAN160015-Liner Sample 5 & 410494005 & Cadmium & 0.124 & 0.37 & $\mathrm{mg} / \mathrm{kg}$ & $\mathrm{B}$ & \\
\hline CFAN160016-Liner Sample 6 & 410494006 & Cadmium & 0.116 & 0.357 & $\mathrm{mg} / \mathrm{kg}$ & $\mathrm{B}$ & \\
\hline CFAN160017-Liner Sample 7 & 410494007 & Cadmium & 0.123 & 0.427 & $\mathrm{mg} / \mathrm{kg}$ & $\mathrm{B}$ & \\
\hline CFAN160018-Liner Sample 8 & 410494008 & Cadmium & 0.119 & 0.303 & $\mathrm{mg} / \mathrm{kg}$ & $\mathrm{B}$ & \\
\hline CFAN160019-Liner Sample 9 & 410494009 & Cadmium & 0.12 & 0.391 & $\mathrm{mg} / \mathrm{kg}$ & $\mathrm{B}$ & \\
\hline CFAN160020-Liner Sample 10 & 410494010 & Cadmium & 0.119 & 0.485 & $\mathrm{mg} / \mathrm{kg}$ & $\mathrm{B}$ & \\
\hline CFAN160021-Liner Sample 11 & 410494011 & Cadmium & 0.126 & 0.697 & $\mathrm{mg} / \mathrm{kg}$ & & \\
\hline CFAN160022-Liner Sample 12 & 410494012 & Cadmium & 0.118 & 0.346 & $\mathrm{mg} / \mathrm{kg}$ & B & \\
\hline CFAN160023-Liner Sample 13 & 410494013 & Cadmium & 0.128 & 0.442 & $\mathrm{mg} / \mathrm{kg}$ & $\mathrm{B}$ & \\
\hline CFAN160024-Liner Sample 14 & 410494014 & Cadmium & 0.12 & 0.377 & $\mathrm{mg} / \mathrm{kg}$ & $\mathrm{B}$ & \\
\hline CFAN160011-Liner Sample 1 & 410494001 & Chromium & 0.185 & 26 & $\mathrm{mg} / \mathrm{kg}$ & & \\
\hline CFAN160012-Liner Sample 2 & 410494002 & Chromium & 0.183 & 26.3 & $\mathrm{mg} / \mathrm{kg}$ & & \\
\hline CFAN160013-Liner Sample 3 & 410494003 & Chromium & 0.191 & 25.8 & $\mathrm{mg} / \mathrm{kg}$ & & \\
\hline CFAN160014-Liner Sample 4 & 410494004 & Chromium & 0.18 & 25 & $\mathrm{mg} / \mathrm{kg}$ & & \\
\hline CFAN160015-Liner Sample 5 & 410494005 & Chromium & 0.185 & 25.8 & $\mathrm{mg} / \mathrm{kg}$ & & \\
\hline CFAN160016-Liner Sample 6 & 410494006 & Chromium & 0.173 & 26.3 & $\mathrm{mg} / \mathrm{kg}$ & & \\
\hline CFAN160017-Liner Sample 7 & 410494007 & Chromium & 0.185 & 27.3 & $\mathrm{mg} / \mathrm{kg}$ & & \\
\hline CFAN160018-Liner Sample 8 & 410494008 & Chromium & 0.179 & 26.1 & $\mathrm{mg} / \mathrm{kg}$ & & \\
\hline CFAN160019-Liner Sample 9 & 410494009 & Chromium & 0.18 & 25.8 & $\mathrm{mg} / \mathrm{kg}$ & & \\
\hline
\end{tabular}




\begin{tabular}{|c|c|c|c|c|c|c|c|}
\hline Sample ID & $\begin{array}{l}\text { Lab Sample } \\
\text { ID }\end{array}$ & Analyte Name & Detection Limit & Result & Units & $\begin{array}{c}\text { Lab } \\
\text { Qualifiers }\end{array}$ & $\begin{array}{c}\text { Validation } \\
\text { Flag }\end{array}$ \\
\hline CFAN160020-Liner Sample 10 & 410494010 & Chromium & 0.178 & 27.3 & $\mathrm{mg} / \mathrm{kg}$ & & \\
\hline CFAN160021-Liner Sample 11 & 410494011 & Chromium & 0.189 & 29 & $\mathrm{mg} / \mathrm{kg}$ & & \\
\hline CFAN160022-Liner Sample 12 & 410494012 & Chromium & 0.178 & 26.6 & $\mathrm{mg} / \mathrm{kg}$ & & \\
\hline CFAN160023-Liner Sample 13 & 410494013 & Chromium & 0.192 & 26.4 & $\mathrm{mg} / \mathrm{kg}$ & & \\
\hline CFAN160024-Liner Sample 14 & 410494014 & Chromium & 0.18 & 25.9 & $\mathrm{mg} / \mathrm{kg}$ & & \\
\hline CFAN160011-Liner Sample 1 & 410494001 & Copper & 0.369 & 27.6 & $\mathrm{mg} / \mathrm{kg}$ & & \\
\hline CFAN160012-Liner Sample 2 & 410494002 & Copper & 0.366 & 35 & $\mathrm{mg} / \mathrm{kg}$ & & \\
\hline CFAN160013-Liner Sample 3 & 410494003 & Copper & 0.382 & 36.4 & $\mathrm{mg} / \mathrm{kg}$ & & \\
\hline CFAN160014-Liner Sample 4 & 410494004 & Copper & 0.359 & 38.2 & $\mathrm{mg} / \mathrm{kg}$ & & \\
\hline CFAN160015-Liner Sample 5 & 410494005 & Copper & 0.371 & 40.5 & $\mathrm{mg} / \mathrm{kg}$ & & \\
\hline CFAN160016-Liner Sample 6 & 410494006 & Copper & 0.347 & 34.7 & $\mathrm{mg} / \mathrm{kg}$ & & \\
\hline CFAN160017-Liner Sample 7 & 410494007 & Copper & 0.37 & 31.1 & $\mathrm{mg} / \mathrm{kg}$ & & \\
\hline CFAN160018-Liner Sample 8 & 410494008 & Copper & 0.357 & 30 & $\mathrm{mg} / \mathrm{kg}$ & & \\
\hline CFAN160019-Liner Sample 9 & 410494009 & Copper & 0.36 & 30.8 & $\mathrm{mg} / \mathrm{kg}$ & & \\
\hline CFAN160020-Liner Sample 10 & 410494010 & Copper & 0.357 & 33.5 & $\mathrm{mg} / \mathrm{kg}$ & & \\
\hline CFAN160021-Liner Sample 11 & 410494011 & Copper & 0.377 & 28.9 & $\mathrm{mg} / \mathrm{kg}$ & & \\
\hline CFAN160022-Liner Sample 12 & 410494012 & Copper & 0.355 & 31.3 & $\mathrm{mg} / \mathrm{kg}$ & & \\
\hline CFAN160023-Liner Sample 13 & 410494013 & Copper & 0.384 & 33.7 & $\mathrm{mg} / \mathrm{kg}$ & & \\
\hline CFAN160024-Liner Sample 14 & 410494014 & Copper & 0.361 & 30.7 & $\mathrm{mg} / \mathrm{kg}$ & & \\
\hline CFAN160011-Liner Sample 1 & 410494001 & Lead & 0.406 & 15.9 & $\mathrm{mg} / \mathrm{kg}$ & & \\
\hline CFAN160012-Liner Sample 2 & 410494002 & Lead & 0.403 & 18.1 & $\mathrm{mg} / \mathrm{kg}$ & & \\
\hline CFAN160013-Liner Sample 3 & 410494003 & Lead & 0.42 & 17.2 & $\mathrm{mg} / \mathrm{kg}$ & & \\
\hline CFAN160014-Liner Sample 4 & 410494004 & Lead & 0.395 & 17.3 & $\mathrm{mg} / \mathrm{kg}$ & & \\
\hline CFAN160015-Liner Sample 5 & 410494005 & Lead & 0.408 & 17.1 & $\mathrm{mg} / \mathrm{kg}$ & & \\
\hline CFAN160016-Liner Sample 6 & 410494006 & Lead & 0.381 & 17.3 & $\mathrm{mg} / \mathrm{kg}$ & & \\
\hline CFAN160017-Liner Sample 7 & 410494007 & Lead & 0.407 & 18.2 & $\mathrm{mg} / \mathrm{kg}$ & & \\
\hline CFAN160018-Liner Sample 8 & 410494008 & Lead & 0.393 & 17.2 & $\mathrm{mg} / \mathrm{kg}$ & & \\
\hline CFAN160019-Liner Sample 9 & 410494009 & Lead & 0.396 & 18.7 & $\mathrm{mg} / \mathrm{kg}$ & & \\
\hline CFAN160020-Liner Sample 10 & 410494010 & Lead & 0.393 & 18.5 & $\mathrm{mg} / \mathrm{kg}$ & & \\
\hline CFAN160021-Liner Sample 11 & 410494011 & Lead & 0.415 & 20.9 & $\mathrm{mg} / \mathrm{kg}$ & & \\
\hline CFAN160022-Liner Sample 12 & 410494012 & Lead & 0.391 & 18.1 & $\mathrm{mg} / \mathrm{kg}$ & & \\
\hline CFAN160023-Liner Sample 13 & 410494013 & Lead & 0.422 & 19.9 & $\mathrm{mg} / \mathrm{kg}$ & & \\
\hline CFAN160024-Liner Sample 14 & 410494014 & Lead & 0.397 & 16.8 & $\mathrm{mg} / \mathrm{kg}$ & & \\
\hline
\end{tabular}




\begin{tabular}{|c|c|c|c|c|c|c|c|}
\hline Sample ID & $\begin{array}{l}\text { Lab Sample } \\
\text { ID }\end{array}$ & Analyte Name & Detection Limit & Result & Units & $\begin{array}{c}\text { Lab } \\
\text { Qualifiers }\end{array}$ & $\begin{array}{c}\text { Validation } \\
\text { Flag }\end{array}$ \\
\hline CFAN160011-Liner Sample 1 & 410494001 & Manganese & 0.246 & 256 & $\mathrm{mg} / \mathrm{kg}$ & & \\
\hline CFAN160012-Liner Sample 2 & 410494002 & Manganese & 0.244 & 234 & $\mathrm{mg} / \mathrm{kg}$ & & \\
\hline CFAN160013-Liner Sample 3 & 410494003 & Manganese & 0.255 & 291 & $\mathrm{mg} / \mathrm{kg}$ & & \\
\hline CFAN160014-Liner Sample 4 & 410494004 & Manganese & 0.24 & 339 & $\mathrm{mg} / \mathrm{kg}$ & & \\
\hline CFAN160015-Liner Sample 5 & 410494005 & Manganese & 0.247 & 307 & $\mathrm{mg} / \mathrm{kg}$ & & \\
\hline CFAN160016-Liner Sample 6 & 410494006 & Manganese & 0.231 & 253 & $\mathrm{mg} / \mathrm{kg}$ & & \\
\hline CFAN160017-Liner Sample 7 & 410494007 & Manganese & 0.247 & 233 & $\mathrm{mg} / \mathrm{kg}$ & & \\
\hline CFAN160018-Liner Sample 8 & 410494008 & Manganese & 0.238 & 278 & $\mathrm{mg} / \mathrm{kg}$ & & \\
\hline CFAN160019-Liner Sample 9 & 410494009 & Manganese & 0.24 & 291 & $\mathrm{mg} / \mathrm{kg}$ & & \\
\hline CFAN160020-Liner Sample 10 & 410494010 & Manganese & 0.238 & 318 & $\mathrm{mg} / \mathrm{kg}$ & & \\
\hline CFAN160021-Liner Sample 11 & 410494011 & Manganese & 0.252 & 610 & $\mathrm{mg} / \mathrm{kg}$ & & \\
\hline CFAN160022-Liner Sample 12 & 410494012 & Manganese & 0.237 & 303 & $\mathrm{mg} / \mathrm{kg}$ & & \\
\hline CFAN160023-Liner Sample 13 & 410494013 & Manganese & 0.256 & 290 & $\mathrm{mg} / \mathrm{kg}$ & & \\
\hline CFAN160024-Liner Sample 14 & 410494014 & Manganese & 0.241 & 271 & $\mathrm{mg} / \mathrm{kg}$ & & \\
\hline CFAN160011-Liner Sample 1 & 410494001 & Mercury & 4.86 & 17.8 & $\mathrm{mg} / \mathrm{kg}$ & & \\
\hline CFAN160012-Liner Sample 2 & 410494002 & Mercury & 4.55 & 20.4 & $\mathrm{mg} / \mathrm{kg}$ & & \\
\hline CFAN160013-Liner Sample 3 & 410494003 & Mercury & 5.14 & 17.9 & $\mathrm{mg} / \mathrm{kg}$ & & \\
\hline CFAN160014-Liner Sample 4 & 410494004 & Mercury & 4.96 & 18.6 & $\mathrm{mg} / \mathrm{kg}$ & & \\
\hline CFAN160015-Liner Sample 5 & 410494005 & Mercury & 4.56 & 17.8 & $\mathrm{mg} / \mathrm{kg}$ & & \\
\hline CFAN160016-Liner Sample 6 & 410494006 & Mercury & 4.64 & 17.1 & $\mathrm{mg} / \mathrm{kg}$ & & \\
\hline CFAN160017-Liner Sample 7 & 410494007 & Mercury & 4.45 & 246 & $\mathrm{mg} / \mathrm{kg}$ & & \\
\hline CFAN160018-Liner Sample 8 & 410494008 & Mercury & 4.29 & 17 & $\mathrm{mg} / \mathrm{kg}$ & & \\
\hline CFAN160019-Liner Sample 9 & 410494009 & Mercury & 4.8 & 17.3 & $\mathrm{mg} / \mathrm{kg}$ & & \\
\hline CFAN160020-Liner Sample 10 & 410494010 & Mercury & 5.03 & 16 & $\mathrm{mg} / \mathrm{kg}$ & & \\
\hline CFAN160021-Liner Sample 11 & 410494011 & Mercury & 5.23 & 25.7 & $\mathrm{mg} / \mathrm{kg}$ & & \\
\hline CFAN160022-Liner Sample 12 & 410494012 & Mercury & 4.54 & 38.9 & $\mathrm{mg} / \mathrm{kg}$ & & \\
\hline CFAN160023-Liner Sample 13 & 410494013 & Mercury & 4.74 & 18.7 & $\mathrm{mg} / \mathrm{kg}$ & & \\
\hline CFAN160024-Liner Sample 14 & 410494014 & Mercury & 4.86 & 16.9 & $\mathrm{mg} / \mathrm{kg}$ & & \\
\hline CFAN160011-Liner Sample 1 & 410494001 & Nickel & 0.185 & 21.6 & $\mathrm{mg} / \mathrm{kg}$ & $\mathrm{E}$ & $\mathrm{J}$ \\
\hline CFAN160012-Liner Sample 2 & 410494002 & Nickel & 0.183 & 23.9 & $\mathrm{mg} / \mathrm{kg}$ & $\mathrm{E}$ & $\mathrm{J}$ \\
\hline CFAN160013-Liner Sample 3 & 410494003 & Nickel & 0.191 & 22.7 & $\mathrm{mg} / \mathrm{kg}$ & $\mathrm{E}$ & $\mathrm{J}$ \\
\hline CFAN160014-Liner Sample 4 & 410494004 & Nickel & 0.18 & 23.1 & $\mathrm{mg} / \mathrm{kg}$ & $\mathrm{E}$ & $\mathrm{J}$ \\
\hline CFAN160015-Liner Sample 5 & 410494005 & Nickel & 0.185 & 22.9 & $\mathrm{mg} / \mathrm{kg}$ & $\mathrm{E}$ & $\mathrm{J}$ \\
\hline
\end{tabular}




\begin{tabular}{|c|c|c|c|c|c|c|c|}
\hline Sample ID & $\begin{array}{c}\text { Lab Sample } \\
\text { ID }\end{array}$ & Analyte Name & Detection Limit & Result & Units & $\begin{array}{c}\text { Lab } \\
\text { Qualifiers }\end{array}$ & $\begin{array}{c}\text { Validation } \\
\text { Flag }\end{array}$ \\
\hline CFAN160016-Liner Sample 6 & 410494006 & Nickel & 0.173 & 23.1 & $\mathrm{mg} / \mathrm{kg}$ & $\mathrm{E}$ & $\mathrm{J}$ \\
\hline CFAN160017-Liner Sample 7 & 410494007 & Nickel & 0.185 & 24.8 & $\mathrm{mg} / \mathrm{kg}$ & $\mathrm{E}$ & $\mathrm{J}$ \\
\hline CFAN160018-Liner Sample 8 & 410494008 & Nickel & 0.179 & 22.5 & $\mathrm{mg} / \mathrm{kg}$ & $\mathrm{E}$ & $\mathrm{J}$ \\
\hline CFAN160019-Liner Sample 9 & 410494009 & Nickel & 0.18 & 22.9 & $\mathrm{mg} / \mathrm{kg}$ & $E$ & $\mathrm{~J}$ \\
\hline CFAN160020-Liner Sample 10 & 410494010 & Nickel & 0.178 & 24.8 & $\mathrm{mg} / \mathrm{kg}$ & $\mathrm{E}$ & $\mathrm{J}$ \\
\hline CFAN160021-Liner Sample 11 & 410494011 & Nickel & 0.189 & 29 & $\mathrm{mg} / \mathrm{kg}$ & $\mathrm{E}$ & $\mathrm{J}$ \\
\hline CFAN160022-Liner Sample 12 & 410494012 & Nickel & 0.178 & 24 & $\mathrm{mg} / \mathrm{kg}$ & $\mathrm{E}$ & $\mathrm{J}$ \\
\hline CFAN160023-Liner Sample 13 & 410494013 & Nickel & 0.192 & 23.8 & $\mathrm{mg} / \mathrm{kg}$ & $\mathrm{E}$ & $\mathrm{J}$ \\
\hline CFAN160024-Liner Sample 14 & 410494014 & Nickel & 0.18 & 23.1 & $\mathrm{mg} / \mathrm{kg}$ & $\mathrm{E}$ & $\mathrm{J}$ \\
\hline CFAN160011-Liner Sample 1 & 410494001 & Selenium & 0.616 & 1.69 & $\mathrm{mg} / \mathrm{kg}$ & $\mathrm{B}$ & \\
\hline CFAN160012-Liner Sample 2 & 410494002 & Selenium & 0.61 & 1.28 & $\mathrm{mg} / \mathrm{kg}$ & $\mathrm{B}$ & \\
\hline CFAN160013-Liner Sample 3 & 410494003 & Selenium & 0.637 & 1.57 & $\mathrm{mg} / \mathrm{kg}$ & $\mathrm{B}$ & \\
\hline CFAN160014-Liner Sample 4 & 410494004 & Selenium & 0.599 & 1.33 & $\mathrm{mg} / \mathrm{kg}$ & $\mathrm{B}$ & \\
\hline CFAN160015-Liner Sample 5 & 410494005 & Selenium & 0.618 & 1.28 & $\mathrm{mg} / \mathrm{kg}$ & $\mathrm{B}$ & \\
\hline CFAN160016-Liner Sample 6 & 410494006 & Selenium & 0.578 & 0.959 & $\mathrm{mg} / \mathrm{kg}$ & $\mathrm{B}$ & \\
\hline CFAN160017-Liner Sample 7 & 410494007 & Selenium & 0.617 & 1.33 & $\mathrm{mg} / \mathrm{kg}$ & $\mathrm{B}$ & \\
\hline CFAN160018-Liner Sample 8 & 410494008 & Selenium & 0.596 & 1.48 & $\mathrm{mg} / \mathrm{kg}$ & $\mathrm{B}$ & \\
\hline CFAN160019-Liner Sample 9 & 410494009 & Selenium & 0.6 & 1.47 & $\mathrm{mg} / \mathrm{kg}$ & $\mathrm{B}$ & \\
\hline CFAN160020-Liner Sample 10 & 410494010 & Selenium & 0.595 & 1.6 & $\mathrm{mg} / \mathrm{kg}$ & $\mathrm{B}$ & \\
\hline CFAN160021-Liner Sample 11 & 410494011 & Selenium & 0.629 & 1.7 & $\mathrm{mg} / \mathrm{kg}$ & B & \\
\hline CFAN160022-Liner Sample 12 & 410494012 & Selenium & 0.592 & 1.78 & $\mathrm{mg} / \mathrm{kg}$ & $\mathrm{B}$ & \\
\hline CFAN160023-Liner Sample 13 & 410494013 & Selenium & 0.639 & 1.41 & $\mathrm{mg} / \mathrm{kg}$ & $\mathrm{B}$ & \\
\hline CFAN160024-Liner Sample 14 & 410494014 & Selenium & 0.601 & 1.38 & $\mathrm{mg} / \mathrm{kg}$ & $\mathrm{B}$ & \\
\hline CFAN160011-Liner Sample 1 & 410494001 & Silver & 0.123 & 0.7 & $\mathrm{mg} / \mathrm{kg}$ & & \\
\hline CFAN160012-Liner Sample 2 & 410494002 & Silver & 0.122 & 0.77 & $\mathrm{mg} / \mathrm{kg}$ & & \\
\hline CFAN160013-Liner Sample 3 & 410494003 & Silver & 0.127 & 0.664 & $\mathrm{mg} / \mathrm{kg}$ & & \\
\hline CFAN160014-Liner Sample 4 & 410494004 & Silver & 0.12 & 0.586 & $\mathrm{mg} / \mathrm{kg}$ & $\mathrm{B}$ & \\
\hline CFAN160015-Liner Sample 5 & 410494005 & Silver & 0.124 & 0.709 & $\mathrm{mg} / \mathrm{kg}$ & & \\
\hline CFAN160016-Liner Sample 6 & 410494006 & Silver & 0.116 & 0.732 & $\mathrm{mg} / \mathrm{kg}$ & & \\
\hline CFAN160017-Liner Sample 7 & 410494007 & Silver & 0.123 & 0.803 & $\mathrm{mg} / \mathrm{kg}$ & & \\
\hline CFAN160018-Liner Sample 8 & 410494008 & Silver & 0.119 & 0.826 & $\mathrm{mg} / \mathrm{kg}$ & & \\
\hline CFAN160019-Liner Sample 9 & 410494009 & Silver & 0.12 & 0.762 & $\mathrm{mg} / \mathrm{kg}$ & & \\
\hline CFAN160020-Liner Sample 10 & 410494010 & Silver & 0.119 & 0.725 & $\mathrm{mg} / \mathrm{kg}$ & & \\
\hline
\end{tabular}




\begin{tabular}{|c|c|c|c|c|c|c|c|}
\hline Sample ID & $\begin{array}{c}\text { Lab Sample } \\
\text { ID }\end{array}$ & Analyte Name & Detection Limit & Result & Units & $\begin{array}{c}\text { Lab } \\
\text { Qualifiers }\end{array}$ & $\begin{array}{l}\text { Validation } \\
\text { Flag }\end{array}$ \\
\hline CFAN160021-Liner Sample 11 & 410494011 & Silver & 0.126 & 0.812 & $\mathrm{mg} / \mathrm{kg}$ & & \\
\hline CFAN160022-Liner Sample 12 & 410494012 & Silver & 0.118 & 0.821 & $\mathrm{mg} / \mathrm{kg}$ & & \\
\hline CFAN160023-Liner Sample 13 & 410494013 & Silver & 0.128 & 0.753 & $\mathrm{mg} / \mathrm{kg}$ & & \\
\hline CFAN160024-Liner Sample 14 & 410494014 & Silver & 0.12 & 0.72 & $\mathrm{mg} / \mathrm{kg}$ & & \\
\hline CFAN160011-Liner Sample 1 & 410494001 & Thallium & 0.616 & 0.616 & $\mathrm{mg} / \mathrm{kg}$ & $\mathrm{U}$ & \\
\hline CFAN160012-Liner Sample 2 & 410494002 & Thallium & 0.61 & 0.61 & $\mathrm{mg} / \mathrm{kg}$ & $\mathrm{U}$ & \\
\hline CFAN160013-Liner Sample 3 & 410494003 & Thallium & 0.637 & 0.637 & $\mathrm{mg} / \mathrm{kg}$ & $\mathrm{U}$ & \\
\hline CFAN160014-Liner Sample 4 & 410494004 & Thallium & 0.599 & 0.599 & $\mathrm{mg} / \mathrm{kg}$ & $\mathrm{U}$ & \\
\hline CFAN160015-Liner Sample 5 & 410494005 & Thallium & 0.618 & 0.618 & $\mathrm{mg} / \mathrm{kg}$ & $\mathrm{U}$ & \\
\hline CFAN160016-Liner Sample 6 & 410494006 & Thallium & 0.578 & 0.578 & $\mathrm{mg} / \mathrm{kg}$ & $\mathrm{U}$ & \\
\hline CFAN160017-Liner Sample 7 & 410494007 & Thallium & 0.617 & 0.617 & $\mathrm{mg} / \mathrm{kg}$ & $\mathrm{U}$ & \\
\hline CFAN160018-Liner Sample 8 & 410494008 & Thallium & 0.596 & 0.596 & $\mathrm{mg} / \mathrm{kg}$ & $\mathrm{U}$ & \\
\hline CFAN160019-Liner Sample 9 & 410494009 & Thallium & 0.6 & 0.6 & $\mathrm{mg} / \mathrm{kg}$ & $\mathrm{U}$ & \\
\hline CFAN160020-Liner Sample 10 & 410494010 & Thallium & 0.595 & 0.595 & $\mathrm{mg} / \mathrm{kg}$ & $\mathrm{U}$ & \\
\hline CFAN160021-Liner Sample 11 & 410494011 & Thallium & 0.629 & 0.629 & $\mathrm{mg} / \mathrm{kg}$ & $\mathrm{U}$ & \\
\hline CFAN160022-Liner Sample 12 & 410494012 & Thallium & 0.592 & 0.592 & $\mathrm{mg} / \mathrm{kg}$ & $\mathrm{U}$ & \\
\hline CFAN160023-Liner Sample 13 & 410494013 & Thallium & 0.639 & 0.639 & $\mathrm{mg} / \mathrm{kg}$ & $\mathrm{U}$ & \\
\hline CFAN160024-Liner Sample 14 & 410494014 & Thallium & 0.601 & 0.601 & $\mathrm{mg} / \mathrm{kg}$ & $\mathrm{U}$ & \\
\hline
\end{tabular}


Table A-2. Central Facilities Area Sewage Treatment Plant Lagoon 3 soil/liner organic sample data.

\begin{tabular}{|c|c|c|c|c|c|c|c|}
\hline Sample ID & $\begin{array}{c}\text { Lab } \\
\text { Sample ID }\end{array}$ & Analyte Name & Detection Limit & Result & Units & $\begin{array}{c}\text { Lab } \\
\text { Qualifiers }\end{array}$ & $\begin{array}{l}\text { Validation } \\
\text { Flag }\end{array}$ \\
\hline CFAN160011-Liner Sample 1 & 410494001 & 1,4-Dichlorobenzene & 0.348 & 1.05 & $\mu \mathrm{g} / \mathrm{kg}$ & $\mathrm{U}$ & \\
\hline CFAN160012-Liner Sample 2 & 410494002 & 1,4-Dichlorobenzene & 0.328 & 0.986 & $\mu \mathrm{g} / \mathrm{kg}$ & $\mathrm{U}$ & \\
\hline CFAN160013-Liner Sample 3 & 410494003 & 1,4-Dichlorobenzene & 0.346 & 1.04 & $\mu \mathrm{g} / \mathrm{kg}$ & $\mathrm{U}$ & \\
\hline CFAN160014-Liner Sample 4 & 410494004 & 1,4-Dichlorobenzene & 0.34 & 1.02 & $\mu \mathrm{g} / \mathrm{kg}$ & $\mathrm{U}$ & \\
\hline CFAN160015-Liner Sample 5 & 410494005 & 1,4-Dichlorobenzene & 0.328 & 0.985 & $\mu \mathrm{g} / \mathrm{kg}$ & $\mathrm{U}$ & \\
\hline CFAN160016-Liner Sample 6 & 410494006 & 1,4-Dichlorobenzene & 0.333 & 1 & $\mu \mathrm{g} / \mathrm{kg}$ & $\mathrm{U}$ & \\
\hline CFAN160017-Liner Sample 7 & 410494007 & 1,4-Dichlorobenzene & 0.328 & 0.984 & $\mu \mathrm{g} / \mathrm{kg}$ & $\mathrm{U}$ & \\
\hline CFAN160018-Liner Sample 8 & 410494008 & 1,4-Dichlorobenzene & 0.329 & 0.989 & $\mu \mathrm{g} / \mathrm{kg}$ & $\mathrm{U}$ & \\
\hline CFAN160019-Liner Sample 9 & 410494009 & 1,4-Dichlorobenzene & 0.332 & 0.998 & $\mu \mathrm{g} / \mathrm{kg}$ & $\mathrm{U}$ & \\
\hline CFAN160020-Liner Sample 10 & 410494010 & 1,4-Dichlorobenzene & 0.31 & 0.932 & $\mu \mathrm{g} / \mathrm{kg}$ & $\mathrm{U}$ & \\
\hline CFAN160021-Liner Sample 11 & 410494011 & 1,4-Dichlorobenzene & 0.329 & 0.989 & $\mu \mathrm{g} / \mathrm{kg}$ & $\mathrm{U}$ & \\
\hline CFAN160022-Liner Sample 12 & 410494012 & 1,4-Dichlorobenzene & 0.312 & 0.936 & $\mu \mathrm{g} / \mathrm{kg}$ & $\mathrm{U}$ & \\
\hline CFAN160023-Liner Sample 13 & 410494013 & 1,4-Dichlorobenzene & 0.351 & 1.05 & $\mu \mathrm{g} / \mathrm{kg}$ & $\mathrm{U}$ & \\
\hline CFAN160024-Liner Sample 14 & 410494014 & 1,4-Dichlorobenzene & 0.332 & 0.998 & $\mu \mathrm{g} / \mathrm{kg}$ & $\mathrm{U}$ & \\
\hline CFAN160011-Liner Sample 1 & 410494001 & Benzene & 0.348 & 1.05 & $\mu \mathrm{g} / \mathrm{kg}$ & $\mathrm{U}$ & \\
\hline CFAN160012-Liner Sample 2 & 410494002 & Benzene & 0.328 & 0.986 & $\mu \mathrm{g} / \mathrm{kg}$ & $\mathrm{U}$ & \\
\hline CFAN160013-Liner Sample 3 & 410494003 & Benzene & 0.346 & 1.04 & $\mu \mathrm{g} / \mathrm{kg}$ & $\mathrm{U}$ & \\
\hline CFAN160014-Liner Sample 4 & 410494004 & Benzene & 0.34 & 1.02 & $\mu \mathrm{g} / \mathrm{kg}$ & $\mathrm{U}$ & \\
\hline CFAN160015-Liner Sample 5 & 410494005 & Benzene & 0.328 & 0.985 & $\mu \mathrm{g} / \mathrm{kg}$ & $\mathrm{U}$ & \\
\hline CFAN160016-Liner Sample 6 & 410494006 & Benzene & 0.333 & 1 & $\mu \mathrm{g} / \mathrm{kg}$ & $\mathrm{U}$ & \\
\hline CFAN160017-Liner Sample 7 & 410494007 & Benzene & 0.328 & 0.984 & $\mu \mathrm{g} / \mathrm{kg}$ & $\mathrm{U}$ & \\
\hline CFAN160018-Liner Sample 8 & 410494008 & Benzene & 0.329 & 0.989 & $\mu \mathrm{g} / \mathrm{kg}$ & $\mathrm{U}$ & \\
\hline CFAN160019-Liner Sample 9 & 410494009 & Benzene & 0.332 & 0.998 & $\mu \mathrm{g} / \mathrm{kg}$ & $\mathrm{U}$ & \\
\hline CFAN160020-Liner Sample 10 & 410494010 & Benzene & 0.31 & 0.932 & $\mu \mathrm{g} / \mathrm{kg}$ & $\mathrm{U}$ & \\
\hline CFAN160021-Liner Sample 11 & 410494011 & Benzene & 0.329 & 0.989 & $\mu \mathrm{g} / \mathrm{kg}$ & $\mathrm{U}$ & \\
\hline CFAN160022-Liner Sample 12 & 410494012 & Benzene & 0.312 & 0.936 & $\mu \mathrm{g} / \mathrm{kg}$ & $\mathrm{U}$ & \\
\hline CFAN160023-Liner Sample 13 & 410494013 & Benzene & 0.351 & 1.05 & $\mu \mathrm{g} / \mathrm{kg}$ & $\mathrm{U}$ & \\
\hline CFAN160024-Liner Sample 14 & 410494014 & Benzene & 0.332 & 0.998 & $\mu \mathrm{g} / \mathrm{kg}$ & $\mathrm{U}$ & \\
\hline CFAN160011-Liner Sample 1 & 410494001 & Ethylbenzene & 0.348 & 1.05 & $\mu \mathrm{g} / \mathrm{kg}$ & $\mathrm{U}$ & \\
\hline CFAN160012-Liner Sample 2 & 410494002 & Ethylbenzene & 0.328 & 0.986 & $\mu \mathrm{g} / \mathrm{kg}$ & $\mathrm{U}$ & \\
\hline CFAN160013-Liner Sample 3 & 410494003 & Ethylbenzene & 0.346 & 1.04 & $\mu \mathrm{g} / \mathrm{kg}$ & $\mathrm{U}$ & \\
\hline CFAN160014-Liner Sample 4 & 410494004 & Ethylbenzene & 0.34 & 1.02 & $\mu \mathrm{g} / \mathrm{kg}$ & $\mathrm{U}$ & \\
\hline
\end{tabular}




\begin{tabular}{|c|c|c|c|c|c|c|c|}
\hline CFAN160015-Liner Sample 5 & 410494005 & Ethylbenzene & 0.328 & 0.985 & $\mu \mathrm{g} / \mathrm{kg}$ & $\mathrm{U}$ & \\
\hline CFAN160016-Liner Sample 6 & 410494006 & Ethylbenzene & 0.333 & 1 & $\mu \mathrm{g} / \mathrm{kg}$ & $\mathrm{U}$ & \\
\hline CFAN160017-Liner Sample 7 & 410494007 & Ethylbenzene & 0.328 & 0.984 & $\mu \mathrm{g} / \mathrm{kg}$ & $\mathrm{U}$ & \\
\hline CFAN160018-Liner Sample 8 & 410494008 & Ethylbenzene & 0.329 & 0.989 & $\mu \mathrm{g} / \mathrm{kg}$ & $\mathrm{U}$ & \\
\hline CFAN160019-Liner Sample 9 & 410494009 & Ethylbenzene & 0.332 & 0.998 & $\mu \mathrm{g} / \mathrm{kg}$ & $\mathrm{U}$ & \\
\hline CFAN160020-Liner Sample 10 & 410494010 & Ethylbenzene & 0.31 & 0.932 & $\mu \mathrm{g} / \mathrm{kg}$ & $\mathrm{U}$ & \\
\hline CFAN160021-Liner Sample 11 & 410494011 & Ethylbenzene & 0.329 & 0.989 & $\mu \mathrm{g} / \mathrm{kg}$ & $\mathrm{U}$ & \\
\hline CFAN160022-Liner Sample 12 & 410494012 & Ethylbenzene & 0.312 & 0.936 & $\mu \mathrm{g} / \mathrm{kg}$ & $\mathrm{U}$ & \\
\hline CFAN160023-Liner Sample 13 & 410494013 & Ethylbenzene & 0.351 & 1.05 & $\mu \mathrm{g} / \mathrm{kg}$ & $\mathrm{U}$ & \\
\hline CFAN160024-Liner Sample 14 & 410494014 & Ethylbenzene & 0.332 & 0.998 & $\mu \mathrm{g} / \mathrm{kg}$ & $\mathrm{U}$ & \\
\hline CFAN160011-Liner Sample 1 & 410494001 & Methylene chloride & 1.74 & 5.23 & $\mu \mathrm{g} / \mathrm{kg}$ & $\mathrm{U}$ & \\
\hline CFAN160012-Liner Sample 2 & 410494002 & Methylene chloride & 1.64 & 4.93 & $\mu \mathrm{g} / \mathrm{kg}$ & $\mathrm{U}$ & \\
\hline CFAN160013-Liner Sample 3 & 410494003 & Methylene chloride & 1.73 & 5.2 & $\mu \mathrm{g} / \mathrm{kg}$ & $\mathrm{U}$ & \\
\hline CFAN160014-Liner Sample 4 & 410494004 & Methylene chloride & 1.7 & 5.1 & $\mu \mathrm{g} / \mathrm{kg}$ & $\mathrm{U}$ & \\
\hline CFAN160015-Liner Sample 5 & 410494005 & Methylene chloride & 1.64 & 4.92 & $\mu \mathrm{g} / \mathrm{kg}$ & $\mathrm{U}$ & \\
\hline CFAN160016-Liner Sample 6 & 410494006 & Methylene chloride & 1.67 & 5.01 & $\mu \mathrm{g} / \mathrm{kg}$ & $\mathrm{U}$ & \\
\hline CFAN160017-Liner Sample 7 & 410494007 & Methylene chloride & 1.64 & 4.92 & $\mu \mathrm{g} / \mathrm{kg}$ & $\mathrm{U}$ & \\
\hline CFAN160018-Liner Sample 8 & 410494008 & Methylene chloride & 1.65 & 4.94 & $\mu \mathrm{g} / \mathrm{kg}$ & $\mathrm{U}$ & \\
\hline CFAN160019-Liner Sample 9 & 410494009 & Methylene chloride & 1.66 & 4.99 & $\mu \mathrm{g} / \mathrm{kg}$ & $\mathrm{U}$ & \\
\hline CFAN160020-Liner Sample 10 & 410494010 & Methylene chloride & 1.55 & 2.27 & $\mu \mathrm{g} / \mathrm{kg}$ & $\mathrm{J}$ & $\mathrm{J}$ \\
\hline CFAN160021-Liner Sample 11 & 410494011 & Methylene chloride & 1.65 & 4.95 & $\mu \mathrm{g} / \mathrm{kg}$ & $\mathrm{U}$ & \\
\hline CFAN160022-Liner Sample 12 & 410494012 & Methylene chloride & 1.56 & 4.68 & $\mu \mathrm{g} / \mathrm{kg}$ & $\mathrm{U}$ & \\
\hline CFAN160023-Liner Sample 13 & 410494013 & Methylene chloride & 1.76 & 5.27 & $\mu \mathrm{g} / \mathrm{kg}$ & $\mathrm{U}$ & \\
\hline CFAN160024-Liner Sample 14 & 410494014 & Methylene chloride & 1.66 & 4.99 & $\mu \mathrm{g} / \mathrm{kg}$ & $\mathrm{U}$ & \\
\hline CFAN160011-Liner Sample 1 & 410494001 & Toluene & 0.348 & 1.05 & $\mu \mathrm{g} / \mathrm{kg}$ & $\mathrm{U}$ & \\
\hline CFAN160012-Liner Sample 2 & 410494002 & Toluene & 0.328 & 0.986 & $\mu \mathrm{g} / \mathrm{kg}$ & $\mathrm{U}$ & \\
\hline CFAN160013-Liner Sample 3 & 410494003 & Toluene & 0.346 & 1.04 & $\mu \mathrm{g} / \mathrm{kg}$ & $\mathrm{U}$ & \\
\hline CFAN160014-Liner Sample 4 & 410494004 & Toluene & 0.34 & 1.02 & $\mu \mathrm{g} / \mathrm{kg}$ & $\mathrm{U}$ & \\
\hline CFAN160015-Liner Sample 5 & 410494005 & Toluene & 0.328 & 0.985 & $\mu \mathrm{g} / \mathrm{kg}$ & $\mathrm{U}$ & \\
\hline CFAN160016-Liner Sample 6 & 410494006 & Toluene & 0.333 & 1 & $\mu \mathrm{g} / \mathrm{kg}$ & $\mathrm{U}$ & \\
\hline CFAN160017-Liner Sample 7 & 410494007 & Toluene & 0.328 & 0.984 & $\mu \mathrm{g} / \mathrm{kg}$ & $\mathrm{U}$ & \\
\hline CFAN160018-Liner Sample 8 & 410494008 & Toluene & 0.329 & 0.989 & $\mu \mathrm{g} / \mathrm{kg}$ & $\mathrm{U}$ & \\
\hline CFAN160019-Liner Sample 9 & 410494009 & Toluene & 0.332 & 0.998 & $\mu \mathrm{g} / \mathrm{kg}$ & $\mathrm{U}$ & \\
\hline CFAN160020-Liner Sample 10 & 410494010 & Toluene & 0.31 & 0.932 & $\mu \mathrm{g} / \mathrm{kg}$ & $\mathrm{U}$ & \\
\hline CFAN160021-Liner Sample 11 & 410494011 & Toluene & 0.329 & 0.989 & $\mu \mathrm{g} / \mathrm{kg}$ & $\mathrm{U}$ & \\
\hline
\end{tabular}




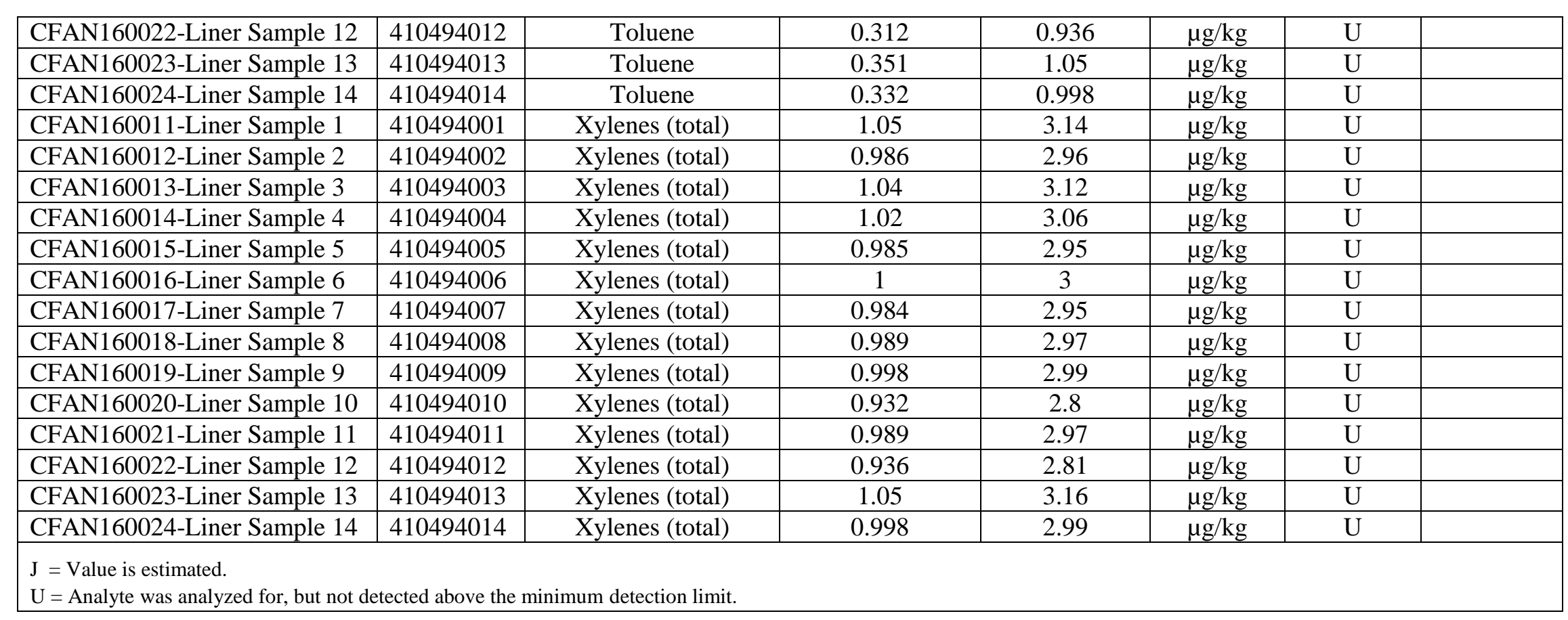


Table A-3. Central Facilities Area Sewage Treatment Plant Lagoon 3 soil/liner radiological sample data.

\begin{tabular}{|c|c|c|c|c|c|c|c|}
\hline Sample ID & $\begin{array}{c}\text { Lab } \\
\text { Sample ID }\end{array}$ & Analyte Name & Detection Limit & Result & Units & $\begin{array}{c}\text { Lab } \\
\text { Qualifiers }\end{array}$ & \begin{tabular}{|c|} 
Validation \\
Flag \\
\end{tabular} \\
\hline CFAN160011-Liner Sample 1 & 410494001 & Cs-137 & 0.0522 & 0.0231 & $\mathrm{pCi} / \mathrm{g}$ & $\mathrm{U}$ & $\mathrm{U}$ \\
\hline CFAN160012-Liner Sample 2 & 410494002 & Cs-137 & 0.0428 & 0.0164 & $\mathrm{pCi} / \mathrm{g}$ & $\mathrm{U}$ & $\mathrm{U}$ \\
\hline CFAN160013-Liner Sample 3 & 410494003 & Cs-137 & 0.0406 & 0.0186 & $\mathrm{pCi} / \mathrm{g}$ & $\mathrm{U}$ & $\mathrm{U}$ \\
\hline CFAN160014-Liner Sample 4 & 410494004 & Cs-137 & 0.0491 & 0.0103 & $\mathrm{pCi} / \mathrm{g}$ & $\mathrm{U}$ & $\mathrm{U}$ \\
\hline CFAN160015-Liner Sample 5 & 410494005 & Cs-137 & 0.0513 & 0.03 & $\mathrm{pCi} / \mathrm{g}$ & $\mathrm{U}$ & UJ \\
\hline CFAN160016-Liner Sample 6 & 410494006 & Cs-137 & 0.049 & 0.0184 & $\mathrm{pCi} / \mathrm{g}$ & $\mathrm{U}$ & $\mathrm{U}$ \\
\hline CFAN160017-Liner Sample 7 & 410494007 & Cs-137 & 0.0465 & 0 & $\mathrm{pCi} / \mathrm{g}$ & UI & $\mathrm{U}$ \\
\hline CFAN160018-Liner Sample 8 & 410494008 & Cs-137 & 0.0523 & -0.0172 & $\mathrm{pCi} / \mathrm{g}$ & $\mathrm{U}$ & $\mathrm{U}$ \\
\hline CFAN160019-Liner Sample 9 & 410494009 & Cs-137 & 0.0528 & 0.0442 & $\mathrm{pCi} / \mathrm{g}$ & $\mathrm{U}$ & UJ \\
\hline CFAN160020-Liner Sample 10 & 410494010 & Cs-137 & 0.0415 & -0.0147 & $\mathrm{pCi} / \mathrm{g}$ & $\mathrm{U}$ & $\mathrm{U}$ \\
\hline CFAN160021-Liner Sample 11 & 410494011 & Cs-137 & 0.0457 & 0.0183 & $\mathrm{pCi} / \mathrm{g}$ & $\mathrm{U}$ & $\mathrm{U}$ \\
\hline CFAN160022-Liner Sample 12 & 410494012 & Cs-137 & 0.0417 & 0.0246 & $\mathrm{pCi} / \mathrm{g}$ & $\mathrm{U}$ & $\mathrm{U}$ \\
\hline CFAN160023-Liner Sample 13 & 410494013 & Cs-137 & 0.0294 & 0.0251 & $\mathrm{pCi} / \mathrm{g}$ & $\mathrm{U}$ & $\mathrm{U}$ \\
\hline CFAN160024-Liner Sample 14 & 410494014 & Cs-137 & 0.0408 & -0.0165 & $\mathrm{pCi} / \mathrm{g}$ & $\mathrm{U}$ & $\mathrm{U}$ \\
\hline CFAN160011-Liner Sample 1 & 410494001 & $\mathrm{H}-3$ & 4.49 & 2.47 & $\mathrm{pCi} / \mathrm{g}$ & $\mathrm{U}$ & $\mathrm{U}$ \\
\hline CFAN160012-Liner Sample 2 & 410494002 & $\mathrm{H}-3$ & 4.4 & 0.183 & $\mathrm{pCi} / \mathrm{g}$ & $\mathrm{U}$ & $\mathrm{U}$ \\
\hline CFAN160013-Liner Sample 3 & 410494003 & $\mathrm{H}-3$ & 4.27 & -0.434 & $\mathrm{pCi} / \mathrm{g}$ & $\mathrm{U}$ & $\mathrm{U}$ \\
\hline CFAN160014-Liner Sample 4 & 410494004 & $\mathrm{H}-3$ & 4.21 & 0.962 & $\mathrm{pCi} / \mathrm{g}$ & $\mathrm{U}$ & $\mathrm{U}$ \\
\hline CFAN160015-Liner Sample 5 & 410494005 & $\mathrm{H}-3$ & 4.35 & 0.272 & $\mathrm{pCi} / \mathrm{g}$ & $\mathrm{U}$ & $\mathrm{U}$ \\
\hline CFAN160016-Liner Sample 6 & 410494006 & $\mathrm{H}-3$ & 4.27 & 0.0109 & $\mathrm{pCi} / \mathrm{g}$ & $\mathrm{U}$ & $\mathrm{U}$ \\
\hline CFAN160017-Liner Sample 7 & 410494007 & $\mathrm{H}-3$ & 4.27 & 1.89 & $\mathrm{pCi} / \mathrm{g}$ & $\mathrm{U}$ & $\mathrm{U}$ \\
\hline CFAN160018-Liner Sample 8 & 410494008 & $\mathrm{H}-3$ & 4.23 & 2.62 & $\mathrm{pCi} / \mathrm{g}$ & $\mathrm{U}$ & $\mathrm{U}$ \\
\hline CFAN160019-Liner Sample 9 & 410494009 & $\mathrm{H}-3$ & 3.99 & 0.313 & $\mathrm{pCi} / \mathrm{g}$ & $\mathrm{U}$ & $\mathrm{U}$ \\
\hline CFAN160020-Liner Sample 10 & 410494010 & $\mathrm{H}-3$ & 4.29 & 0.872 & $\mathrm{pCi} / \mathrm{g}$ & $\mathrm{U}$ & $\mathrm{U}$ \\
\hline CFAN160021-Liner Sample 11 & 410494011 & $\mathrm{H}-3$ & 4.13 & 0.873 & $\mathrm{pCi} / \mathrm{g}$ & $\mathrm{U}$ & $\mathrm{U}$ \\
\hline CFAN160022-Liner Sample 12 & 410494012 & $\mathrm{H}-3$ & 4.17 & 0.992 & $\mathrm{pCi} / \mathrm{g}$ & $\mathrm{U}$ & $\mathrm{U}$ \\
\hline CFAN160023-Liner Sample 13 & 410494013 & $\mathrm{H}-3$ & 4.22 & 3.39 & $\mathrm{pCi} / \mathrm{g}$ & $\mathrm{U}$ & UJ \\
\hline CFAN160024-Liner Sample 14 & 410494014 & $\mathrm{H}-3$ & 4.02 & 0.269 & $\mathrm{pCi} / \mathrm{g}$ & $\mathrm{U}$ & $\mathrm{U}$ \\
\hline CFAN160011-Liner Sample 1 & 410494001 & I-129 & 1.11 & 0.15 & $\mathrm{pCi} / \mathrm{g}$ & $\mathrm{U}$ & $\mathrm{U}$ \\
\hline CFAN160012-Liner Sample 2 & 410494002 & $\mathrm{I}-129$ & 0.994 & 0.0653 & $\mathrm{pCi} / \mathrm{g}$ & $\mathrm{U}$ & $\mathrm{U}$ \\
\hline CFAN160013-Liner Sample 3 & 410494003 & I-129 & 0.77 & -0.0313 & $\mathrm{pCi} / \mathrm{g}$ & $\mathrm{U}$ & $\mathrm{U}$ \\
\hline CFAN160014-Liner Sample 4 & 410494004 & $\mathrm{I}-129$ & 0.647 & -0.231 & $\mathrm{pCi} / \mathrm{g}$ & $\mathrm{U}$ & $\mathrm{U}$ \\
\hline
\end{tabular}




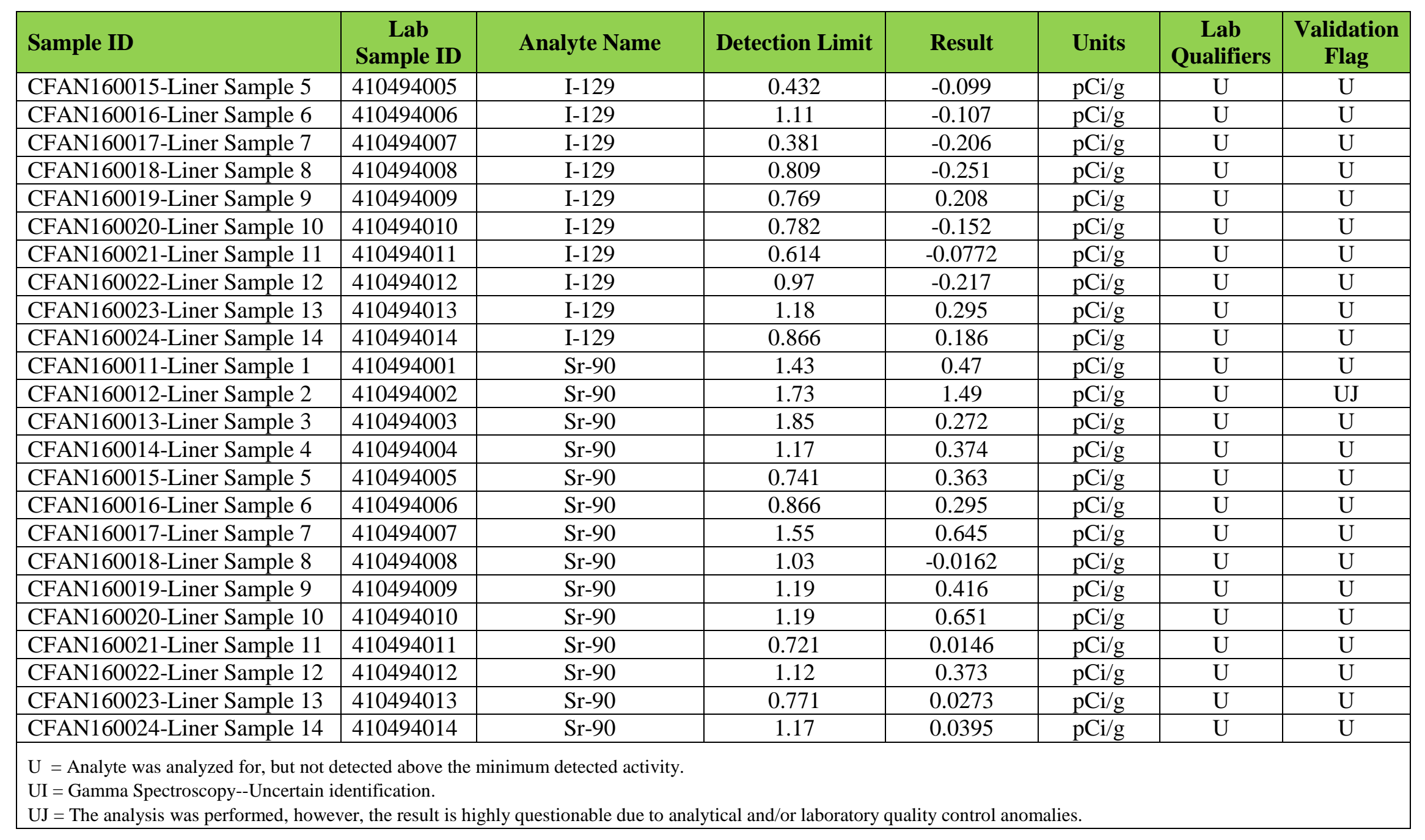

